Check for updates

Cite this: RSC Adv., 2017, 7, 29752

\title{
Synthesis, structure and reactivity of guanidinate rare earth metal bis(o-aminobenzyl) complexes $\uparrow$
}

\author{
Feng Kong, (D) Meng Li, (D) Xigeng Zhou (D) and Lixin Zhang (D) *
}

A series of guanidinate rare-earth metal complexes $\left[\left(\mathrm{PhCH}_{2}\right)_{2} \mathrm{NC}\left(\mathrm{NC}_{6} \mathrm{H}_{4}{ }^{i} \mathrm{Pr}_{2}-2,6\right)_{2}\right] \mathrm{RE}\left(\mathrm{CH}_{2} \mathrm{C}_{6} \mathrm{H}_{4} \mathrm{NMe}_{2}-\mathrm{O}\right)_{2}$ $\left(R E=Y(2 a)\right.$, La (2b), Dy (2c), Lu (2d)) were synthesized by the acid-base reaction of $\mathrm{RE}\left(\mathrm{CH}_{2} \mathrm{C}_{6} \mathrm{H}_{4} \mathrm{NMe}_{2}\right.$ o) 3 with $\left(\mathrm{PhCH}_{2}\right)_{2} \mathrm{~N}[\mathrm{C}(\mathrm{NHR})=(\mathrm{NR})]\left(\mathrm{R}=2,6-{ }^{i} \mathrm{Pr}_{2}-\mathrm{C}_{6} \mathrm{H}_{3}\right)$ (1) in THF. Treatment of complexes 2 with two equivalents of carbon dioxide, sulfur and phenyl isothiocyanate gave the corresponding insertion products $\left\{\left[\left(\mathrm{PhCH}_{2}\right)_{2} \mathrm{NC}\left(\mathrm{NC}_{6} \mathrm{H}_{4}{ }^{i} \mathrm{Pr}_{2}-2,6\right)_{2}\right] \mathrm{RE}\left(\mu-\eta^{2}: \eta^{1}-\mathrm{O}_{2} \mathrm{CCH}_{2} \mathrm{C}_{6} \mathrm{H}_{4} \mathrm{NMe}_{2}-O\right)\left(\mu-\eta^{1}: \eta^{1}-\mathrm{O}_{2} \mathrm{CCH}_{2} \mathrm{C}_{6} \mathrm{H}_{4} \mathrm{NMe}_{2}-\right.\right.$ $0)\}_{2}(\mathrm{RE}=\mathrm{Y}(3 \mathrm{a}), \mathrm{La}(3 \mathrm{~b}), \mathrm{Dy}(3 \mathrm{c}), \mathrm{Lu}(3 \mathrm{~d})),\left\{\left[\left(\mathrm{PhCH}_{2}\right)_{2} \mathrm{NC}\left(\mathrm{NC}_{6} \mathrm{H}_{4}{ }^{i} \mathrm{Pr}_{2}-2,6\right)_{2}\right] \mathrm{RE}\left[\mu-\mathrm{S}\left(\mathrm{CH}_{2} \mathrm{C}_{6} \mathrm{H}_{4} \mathrm{NMe}_{2}-\mathrm{O}\right)\right]_{2}\right\}_{2}$

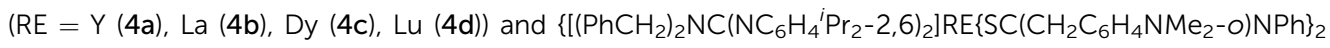
$(R E=Y(5 a), L a(5 b)$, Dy $(5 c), L u(5 d))$ in good yields, respectively. All new complexes were fully characterized by NMR spectroscopy and elemental analysis. The structures of 1, 2d, 3, 4a, 4c-d, 5a, and $5 c-d$ were established by $X$-ray diffraction studies. Complexes 2 were found to have a high activity and excellent 3,4-selectivity for isoprene polymerization in the presence of $\left[\mathrm{Ph}_{3} \mathrm{C}\right]\left[\mathrm{B}\left(\mathrm{C}_{6} \mathrm{~F}_{5}\right)_{4}\right]$.

Received 22nd April 2017 Accepted 23rd May 2017

DOI: $10.1039 / \mathrm{c} 7 \mathrm{ra0} 4524 \mathrm{~g}$

rsc.li/rsc-advances
In order to further explore the effect of subtle ligand change on the reaction patterns of rare-earth bis(alkyl) complexes, we designed a new bulky tetraalkylated guanidinate with two benzyl groups at the axis $\mathrm{N}$ atom. Herein, we report the synthesis of this new guanidine and the corresponding rareearth bis(alkyl) complexes. The reactions of the dialkyl species with small molecules, such as $\mathrm{CO}_{2}, \mathrm{~S}_{8}$, and PhNCS are also disclosed. Moreover, the catalytic performance of the mono(guanidiante) rare-earth bis(alkyl) complexes for isoprene polymerization will be discussed as well.

\section{Results and discussion}

\subsection{Synthesis of $\left(\mathrm{PhCH}_{2}\right)_{2} \mathrm{~N}[\mathrm{C}(\mathrm{NHR})=(\mathrm{NR})]\left(\mathrm{R}=2,6{ }^{i}-\mathrm{Pr}_{2} \mathrm{C}_{6} \mathrm{H}_{3}\right)(\mathbf{1})$}

The neutral guanidinate compound $\left(\mathrm{PhCH}_{2}\right)_{2} \mathrm{~N}[\mathrm{C}(\mathrm{NHR})=\mathrm{NR}]$ $\left(\mathrm{R}=2,6-{ }^{i} \mathrm{Pr}_{2} \mathrm{C}_{6} \mathrm{H}_{3}\right)$ (1) was synthesized in good yield by the reaction of lithium dibenzylamido with one equivalent of carbodiimide (Scheme 1). Compound 1 was characterized by NMR spectroscopy and X-ray structural analysis. The X-ray diffraction reveals that the $\Delta \mathrm{CN}$ parameter of complex 1 is $0.102 \AA$ (Fig. 1 ), which shows the difference in interatomic distance in the supposed "double" and "single" bonds is very evident. This compound is very easy to dissolve in hexane, toluene and THF. In the ${ }^{1} \mathrm{H}$ NMR spectrum (in $\mathrm{CDCl}_{3}$ ) of $\mathbf{1}$, four doublets at $\delta=$ $1.34,1.25,1.05$ and $0.91 \mathrm{ppm}$ can be assigned to methyl protons, and the multiples appear at 3.31-3.20 assignable to methine protons. After scrutiny of the ${ }^{1} \mathrm{H}$ NMR spectrum (in $\mathrm{CDCl}_{3}$ ), we found that the multiples were formed by two sets of overlapped multiples. And this was further confirmed by the ${ }^{13} \mathrm{C}$ NMR spectrum (in $\mathrm{CDCl}_{3}$ ): two resonances at $\delta=29.0$ and 28.4 ppm can be assigned to methine carbons of the $-\mathrm{CHMe}_{2}$ 


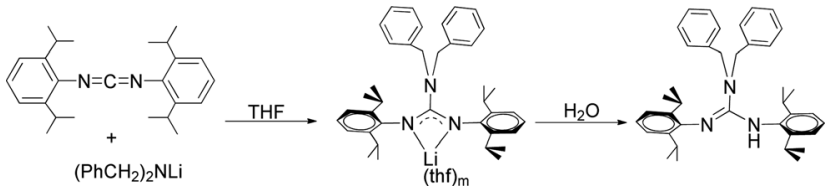

Scheme 1

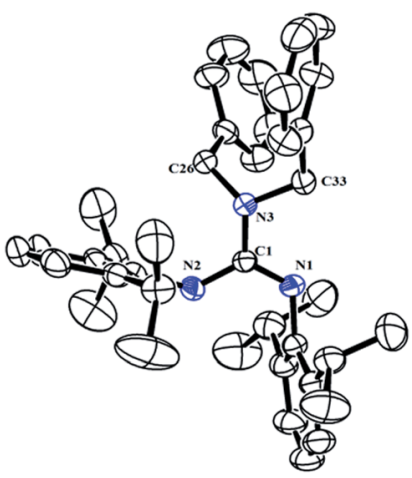

Fig. 1 Molecular structure of complex 1 with thermal ellipsoids at 30\% probability. All of the hydrogen atoms are omitted for clarity. Selected bond distances $(\AA \AA)$ and angles $\left({ }^{\circ}\right)$ : C(1)-N(1) 1.269(3), C(1)-N(2) 1.371(3), $C(1)-N(3)$ 1.389(3), C(26)-N(3) 1.454(3), C(33)-N(3) 1.474(3), N(2)-C(1) 1.371(3); $C(1)-N(1)-C(2) 121.1(2), C(1)-N(2)-C(14) 132.7(2), N(1)-C(1)-N(2)$ 122.8(2), $N(1)-C(1)-N(3)$ 119.1(2), N(2)-C(1)-N(3) 118.1(2), $C(1)-N(3)-C(26)$ 121.61(19), $C(1)-N(3)-C(33) 115.15(18), C(26)-N(3)-C(33) 114.26(18)$.

units. Besides, we further collected the NMR spectra of 1 in $\mathrm{C}_{6} \mathrm{D}_{6}$, and in the ${ }^{1} \mathrm{H}$ NMR spectrum (in $\mathrm{C}_{6} \mathrm{D}_{6}$ ) of $\mathbf{1}$, the signals of methine protons in $-\mathrm{CHMe}_{2}$ units appear as multiple peaks at $\delta=3.50$ and $3.35 \mathrm{ppm}$. In its ${ }^{13} \mathrm{C}$ NMR spectrum (in $\mathrm{C}_{6} \mathrm{D}_{6}$ ), corresponding carbon resonances appear at $\delta=29.3$ and 28.6 ppm respectively.

\subsection{Synthesis of $\left[\left(\mathrm{PhCH}_{2}\right)_{2} \mathrm{NC}\left(\mathrm{NC}_{6} \mathrm{H}_{4}{ }^{i} \mathrm{Pr}_{2} 2,6\right)_{2}\right] \mathrm{RE}$ $\left(\mathrm{CH}_{2} \mathrm{C}_{6} \mathrm{H}_{4} \mathrm{NMe}_{2}-\mathrm{o}\right)_{2}(\mathrm{RE}=\mathrm{Y}(2 \mathrm{a}), \mathrm{La}(2 \mathrm{~b}), \mathrm{Dy}(2 \mathrm{c}), \mathrm{Lu}(2 \mathrm{~d}))$}

As shown in Scheme 2, treatment of $\mathrm{RE}\left(\mathrm{CH}_{2} \mathrm{C}_{6} \mathrm{H}_{4} \mathrm{NMe}_{2}-\mathrm{O}\right)_{3}$ with 1 afforded the guanidinate-stabilized bis(aminobenzyl) complexes $\left[\left(\mathrm{PhCH}_{2}\right)_{2} \mathrm{NC}\left(\mathrm{NC}_{6} \mathrm{H}_{3}{ }^{i} \mathrm{Pr}_{2}-2,6\right)_{2}\right] \mathrm{RE}\left(\mathrm{CH}_{2} \mathrm{C}_{6} \mathrm{H}_{4} \mathrm{NMe}_{2}-\mathrm{O}\right)_{2}(\mathrm{RE}=\mathrm{Y}(\mathbf{2 a})$, La (2b), Dy (2c), Lu (2d)) in moderate yields. All the new compounds were characterized by elemental analysis, NMR spectroscopy (except for $2 \mathrm{c}$ ). In ${ }^{1} \mathrm{H}$ NMR spectra of 2 , the resonances of the methylene protons in aminobenzyl group appear as

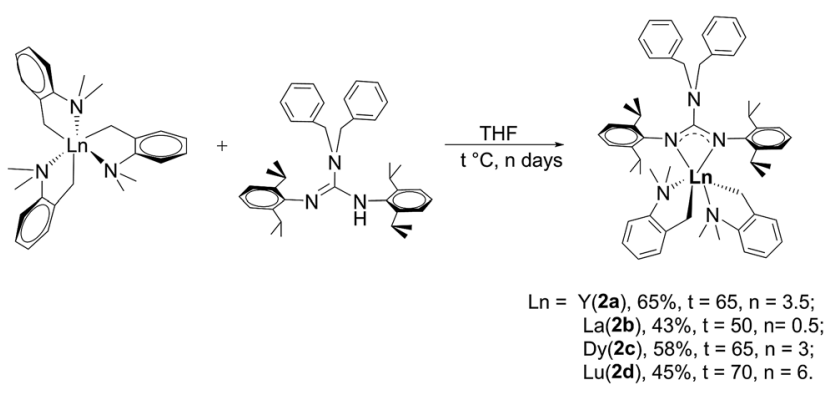

Scheme 2

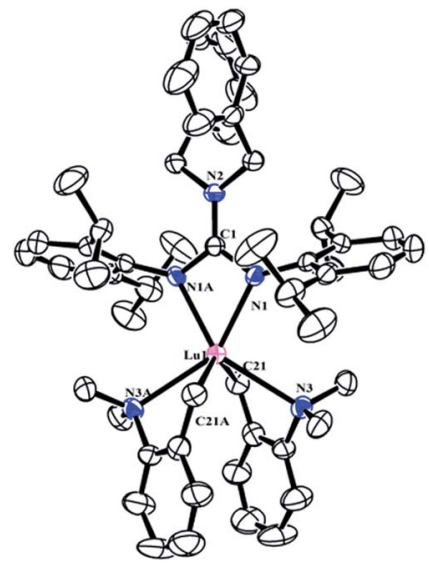

Fig. 2 Molecular structure of complex $2 d$ with thermal ellipsoids at $30 \%$ probability. All of the hydrogen atoms are omitted for clarity. Selected bond distances $(\AA)$ and angles $\left({ }^{\circ}\right)$ : Lu(1) $-N(1)$ 2.318(3), Lu(1)$N(1 A) 2.318(3), L u(1)-N(3) 2.624(3) ; N(1)-C(1)-N(1 A)$ 109.4(4), N(1)$\mathrm{C}(1)-\mathrm{N}(2)$ 125.31(19), N(1A)-C(1)-N(2) 125.31(19), N(1)-Lu(1)-N(1A) $57.07(11)$

sharp singlets at $\delta=1.81(2 \mathrm{a}), 1.84(2 \mathrm{~b})$ and $1.80(2 \mathrm{~d}) \mathrm{ppm}$ respectively. And the signals at $\delta=48.0(2 a), 61.6(2 b)$ and 53.3(2d) in their ${ }^{13} \mathrm{C}$ NMR spectra can be assigned to their corresponding methylene carbons. And the signals of methine protons in the guanidinate ligand of the complexes 2 are observed at $\delta=$ $4.12 \mathrm{ppm}$ for $2 \mathrm{a}, 3.93 \mathrm{ppm}$ for $2 \mathbf{b}$ and $4.20 \mathrm{ppm}$ for $\mathbf{2 d}$, while their corresponding carbon resonances almost remain unchanged, the similar phenomenon was observed in $\left[\left(\mathrm{CH}_{3}\right)_{2} \mathrm{NC}\left(\mathrm{NC}_{6} \mathrm{H}_{4}{ }^{i} \mathrm{Pr}_{2}-2,6\right)_{2}\right]$ $\mathrm{Y}\left(\mathrm{CH}_{2} \mathrm{SiMe}_{3}\right)_{2}$ (THF) and the corresponding neutral ligand $\left(\mathrm{CH}_{3}\right)_{2} \mathrm{~N}[\mathrm{C}(\mathrm{NHR})=(\mathrm{NR})]\left(\mathrm{R}=2,6-{ }^{i} \mathrm{Pr}_{2} \mathrm{C}_{6} \mathrm{H}_{3}\right) \cdot{ }^{6 c}$ Other characteristic peaks can also be assigned clearly. Single crystal X-ray structural analysis of complex $\mathbf{2 d}$ established the distorted-octahedral geometry of its core structure. The structure of $\mathbf{2 d}$ is depicted in Fig. 2; selected bond lengths and angles are listed in the caption. The lutetium atom was coordinated by six atoms: two nitrogen atoms from the guanidinate ligand, two carbon atoms and two amino nitrogen atoms. The guanidinate ligand coordinates symmetrically to the Lu atom. Because of the better symmetry of the coordinated guanidinate ligand, the numbers of the methine and methyl resonances of the ligand decrease in the NMR spectra of complexes 2 in comparison with the neutral ligand. ${ }^{6 c}$ The bond length of $\mathrm{Lu}-\mathrm{N}(2.318(3) \AA)$ is very close to the $\mathrm{Lu}-\mathrm{N}$ distance in $\left[\mathrm{CyC}\left(\mathrm{N}-2,6-{ }^{i} \mathrm{Pr}_{2} \mathrm{C}_{6} \mathrm{H}_{3}\right)_{2}\right] \mathrm{Lu}\left(\mathrm{CH}_{2} \mathrm{SiMe}_{3}\right)_{2}$ (THF) (average $\left.2.313 \AA\right)^{8}$ and slightly shorter than Y-N distance $(2.373 \AA)$ in $\left[\mathrm{PhC}\left(\mathrm{NC}_{6} \mathrm{H}_{4}{ }^{i} \mathrm{Pr}_{2}\right.\right.$ $\left.2,6)_{2}\right] \mathrm{Y}\left(\mathrm{CH}_{2} \mathrm{C}_{6} \mathrm{H}_{4} \mathrm{NMe}_{2}-\mathrm{O}\right)_{2},{ }^{7 b}$ after taking into consideration of the difference between metal radii.

\subsection{Reaction of $\left[\left(\mathrm{PhCH}_{2}\right)_{2} \mathrm{NC}\left(\mathrm{NC}_{6} \mathrm{H}_{4}{ }^{i} \mathrm{Pr}_{2}-2,6\right)_{2}\right] \mathrm{RE}$ $\left(\mathrm{CH}_{2} \mathrm{C}_{6} \mathrm{H}_{4} \mathrm{NMe}_{2}-\mathrm{o}\right)_{2}(\mathrm{RE}=\mathrm{Y}(2 \mathrm{a}), \mathrm{La}(2 \mathrm{~b}), \mathrm{Dy}(2 \mathrm{c}), \mathrm{Lu}(2 \mathrm{~d}))$ with $\mathrm{CO}_{2}$}

To explore the ligand effect on the structure and reactivity of complexes, reactions of complexes 2 with $\mathrm{CO}_{2}$ were conducted firstly. The THF solution of complexes 2 was stirred under an atmosphere of $\mathrm{CO}_{2}(0.1 \mathrm{MPa})$, an immediate colour change from yellow to colourless was observed for complexes $\mathbf{2 b}$ and $\mathbf{2 c}$, while the colour change was not observed in the reaction of $2 \mathbf{a}$ 


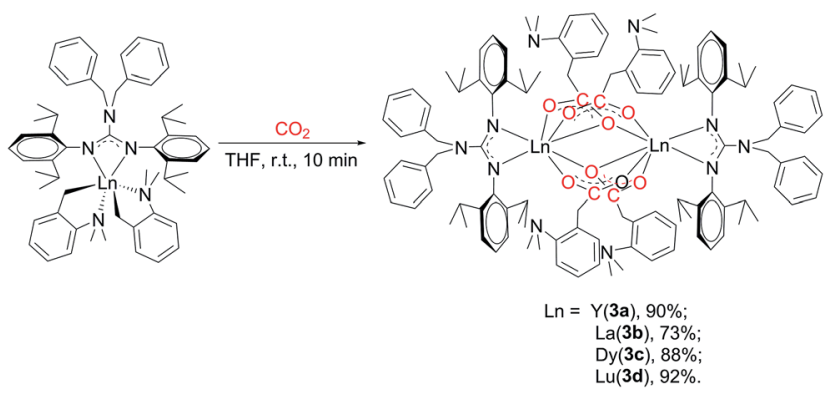

Scheme 3

and 2d (Scheme 3). Expected insertion products $\left\{\left[\left(\mathrm{PhCH}_{2}\right)_{2}-\right.\right.$ $\left.\mathrm{NC}\left(\mathrm{NC}_{6} \mathrm{H}_{4}{ }^{i} \mathrm{Pr}_{2}-2,6\right)_{2}\right] \operatorname{RE}\left(\mu-\eta^{2}: \eta^{1}-\mathrm{O}_{2} \mathrm{CCH}_{2} \mathrm{C}_{6} \mathrm{H}_{4} \mathrm{NMe}_{2}-o\right)\left(\mu-\eta^{1}: \eta^{1}-\right.$ $\left.\left.\mathrm{O}_{2} \mathrm{CCH}_{2} \mathrm{C}_{6} \mathrm{H}_{4} \mathrm{NMe}_{2}-0\right)\right\}_{2}(\mathrm{RE}=\mathrm{Y}(3 \mathbf{a}), \mathrm{La}(3 \mathbf{b})$, Dy (3c), Lu (3d)) were obtained in mediate to excellent yields. In their ${ }^{1} \mathrm{H}$ NMR spectra, the broad peak observed at $\delta=3.47(3 \mathbf{b}), 3.50(3 \mathbf{d}) \mathrm{ppm}$ can be assigned to methylene protons of the aminobenzyl groups. Complex $\mathbf{3 b}$ displays a sharp singlet at $\delta=2.54 \mathrm{ppm}$ assignable for the methyl protons of $-\mathrm{NMe}_{2}$ groups, while for 3d, the methyl signal turns into a set of broad multiple peaks at $\delta=2.52 \mathrm{ppm}$. However, in the room temperature ${ }^{1} \mathrm{H}$ NMR spectrum of 3a, there is only one broad peak at $\delta=2.47 \mathrm{ppm}$ that can be assigned to methylene and methyl protons in the aminobenzyl groups. Compared to their corresponding dialkyl complexes, in complexes 3 (except 3c), the methylene protons of the aminobenzyl groups obviously shift to downfield which indicates the insertion of $\mathrm{CO}_{2}$ molecules. And in their ${ }^{13} \mathrm{C}$ NMR spectra, the resonances at $\delta=186.2(3 \mathbf{a}), 183.6(3 \mathbf{b})$ and $183.7(3 d)$ ppm are assignable to the carbons in carboxyl groups. The structures of complexes 3 were further confirmed by the Xray single crystal diffraction. The $\mathrm{X}$-ray crystallographic analysis indicates that complexes $\mathbf{3 a - d}$ are isostructural, and crystal structure of 3a is presented in Fig. 3. The generated carboxyl units coordinate to lanthanide centres in two different fashions: $\mu-\eta^{2}: \eta^{1}$ and $\mu-\eta^{1}: \eta^{1}$. And the $\mathrm{C}-\mathrm{O}$ bond lengths of complexes 3 range from 1.222(9) $\AA$ to $1.309(8) \AA$, which are consistent with typical delocalized carboxylate species. ${ }^{9}$ The $\mathrm{Y}-\mathrm{O}$ bond length are generally in the normal range except the $\mathrm{Y}(1)-\mathrm{O}(3 \mathrm{~A})$ $(2.737(4) \AA)$ bond. The $\mathrm{Y}(1)-\mathrm{O}(3 \mathrm{~A})$ bond is remarkably longer than those observed in $\left[\left(\mathrm{C}_{5} \mathrm{Me}_{4}\right) \mathrm{SiMe}_{2}\left(\mathrm{CH}_{2} \mathrm{CH}=\mathrm{CH}_{2}\right)\right] \mathrm{Y}\left(\mu-\eta^{2}: \eta^{1}\right.$ $\left.\left.\mathrm{O}_{2} \mathrm{CCH}_{2} \mathrm{SiMe}_{3}\right)\left(\mu-\eta^{1}: \eta^{1}-\mathrm{O}_{2} \mathrm{CCH}_{2} \mathrm{SiMe}_{3}\right)\right\}_{2}$ (ref. 9b) (2.563(2) $\AA$ ) and $\left\{\left[\mathrm{PhC}\left(\mathrm{NC}_{6} \mathrm{H}_{4}{ }^{i} \mathrm{Pr}_{2}-2,6\right)_{2}\right] \mathrm{Y}\left(\mu-\eta^{2}: \eta^{1}-\mathrm{O}_{2} \mathrm{CCH}_{2} \mathrm{C}_{6} \mathrm{H}_{4} \mathrm{NMe}_{2}-o\right)(\mu-\right.$ $\left.\left.\eta^{1}: \eta^{1}-\mathrm{O}_{2} \mathrm{CCH}_{2} \mathrm{C}_{6} \mathrm{H}_{4} \mathrm{NMe}_{2}-o\right)\right\}_{2}(2.53(1) \AA) .{ }^{7 b}$ This unusual bond length can be ascribed to the bulky size and electronic effect of the guanidinate ligand. The poor solubility of complexes 3 even in THF at room temperature can provide extra evidence for the sterically crowded coordination sphere around the lanthanide centres. The reactions of complexes 2 with $\mathrm{CO}_{2}$ provide not only an effective way for the activation of $\mathrm{CO}_{2}$, but also a good synthetic method for guanidinate rare-earth derivatives.

\subsection{Reaction of $\left[\left(\mathrm{PhCH}_{2}\right)_{2} \mathrm{NC}\left(\mathrm{NC}_{6} \mathrm{H}_{4}{ }^{i} \mathrm{Pr}_{2}-2,6\right)_{2}\right] \mathrm{RE}$} $\left(\mathrm{CH}_{2} \mathrm{C}_{6} \mathrm{H}_{4} \mathrm{NMe}_{2}-\mathrm{o}\right)_{2}(\mathrm{RE}=\mathrm{Y}(2 \mathrm{a}), \mathrm{La}(2 \mathrm{~b}), \mathrm{Dy}(2 \mathrm{c}), \mathrm{Lu}(2 \mathrm{~d}))$ with $\mathrm{S}_{8}$

To further study the reactivity of complexes 2 , reactions with $\mathrm{S}_{8}$ were also carried out. Different from their amidinate

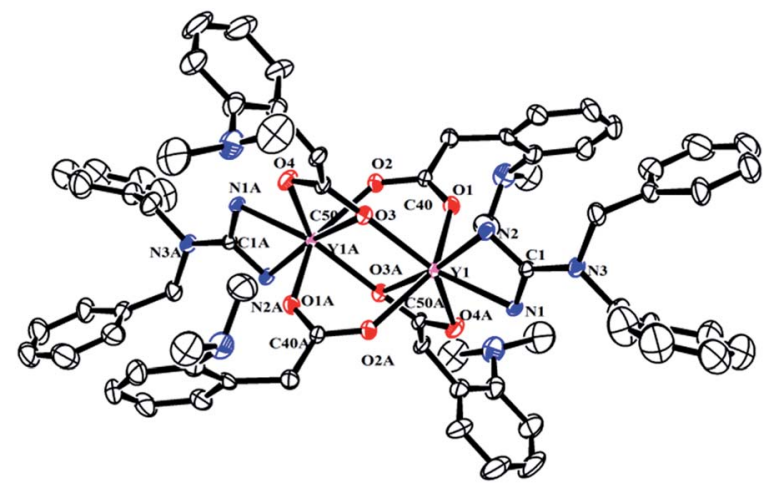

Fig. 3 Molecular structure of complex 3a with thermal ellipsoids at $30 \%$ probability. 2,6-Diisopropylphenyl groups of guanidinate ligand and all of the hydrogen atoms are omitted for clarity. Selected bond distances $(\AA)$ and angles $\left({ }^{\circ}\right)$ : $Y(1)-N(1) 2.318(4), Y(1)-N(2) 2.354(5), Y(1)-$ $O(3) 2.254(4), Y(1)-O(1) 2.269(4), Y(1)-O(2 A) 2.276(4), Y(1)-O(4 A)$ 2.330(4), $\quad Y(1)-O(3 A) \quad 2.737(4), \quad O(1)-C(40)$ 1.259(7), $O(2)-C(40)$ 1.276(6), $O(3)-C(50)$ 1.280(6), $O(4)-C(50)$ 1.257(7); $O(3)-Y(1)-O(1)$ 81.80(15), $O(1)-Y(1)-O(4 A) \quad 85.33(16), O(3)-Y(1)-O(4 A)$ 135.12(15), $O(3)-Y(1)-O(3 A) \quad 84.96(14), O(1)-Y(1)-O(2 A) \quad 141.14(14), N(1)-C(1)-$ $\mathrm{N}(2)$ 110.5(4), $N(1)-Y(1)-N(2) \quad 56.38(15), O(1)-C(40)-O(2) 122.2(5)$, $\mathrm{O}(4)-\mathrm{C}(50)-\mathrm{O}(3) 118.5(5)$.

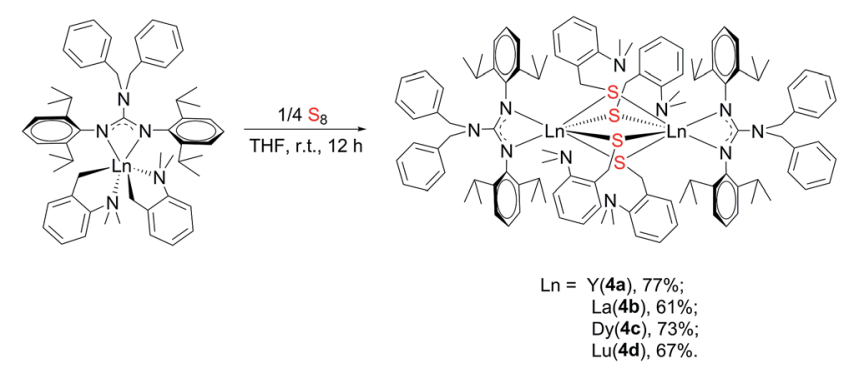

Scheme 4

counterparts ${ }^{7 b}$ the reactions of complexes 2 with $1 / 4$ equivalent $\mathrm{S}_{8}$ gave dinuclear lanthanide insertion products $\left\{\left[\left(\mathrm{PhCH}_{2}\right)_{2}\right.\right.$ $\left.\left.\mathrm{NC}\left(\mathrm{NC}_{6} \mathrm{H}_{4}{ }^{i} \mathrm{Pr}_{2}-2,6\right)_{2}\right] \mathrm{RE}\left[\mu-\mathrm{S}\left(\mathrm{CH}_{2} \mathrm{C}_{6} \mathrm{H}_{4} \mathrm{NMe}_{2}-o\right)\right]_{2}\right\}_{2}(\mathrm{RE}=\mathrm{Y}(\mathbf{4 a}), \mathrm{La}$ (4b), Dy (4c), Lu (4d)) in good yields (Scheme 4). ${ }^{10 d}$ These complexes are easily soluble in toluene and THF, and slightly soluble in hexane. Complexes $\mathbf{4 a}, \mathbf{4 b}$ and $\mathbf{4 d}$ were characterized by the ${ }^{1} \mathrm{H}$ and ${ }^{13} \mathrm{C}$ NMR spectra in $\mathrm{C}_{6} \mathrm{D}_{6}$ at $25^{\circ} \mathrm{C}$. The ${ }^{1} \mathrm{H}$ NMR spectra show multiple signals at $\delta=3.89(4 \mathbf{a}), 3.77(\mathbf{4 b})$ and $3.95(4 \mathbf{d}) \mathrm{ppm}$ which are assignable for the methine protons of the $\mathrm{CHMe}_{2}$ groups. Compared to their corresponding dialkyl complexes, the signals of the methylene protons obviously shift to lower field because of the insertion of the sulfur atoms. For $\mathbf{4 b}$, the signal for the methylene protons of aminobenzyl group appears as a sharp singlet at $\delta=4.52 \mathrm{ppm}$, while for $\mathbf{4 a}$ and $\mathbf{4 d}$, it becomes a broad peak at $\delta=4.28$ and $4.46 \mathrm{ppm}$ respectively. And their corresponding carbon signals show up at $\delta=34.6(4 \mathbf{a}), 33.5(4 \mathbf{b})$ and $34.3(\mathbf{4 d}) \mathrm{ppm}$ as sharp singlets. The X-ray single crystal diffraction analysis established the bimetallic structure of complexes $\mathbf{4 a}, \mathbf{4 c}$ and 4d (Fig. 4). Two yttrium ions are connected by four bridging thiolate units which definitely proves the insertion of sulfur atoms into each of $\mathrm{Y}-\mathrm{C}$ bonds. In lanthanide chemistry, the similar core 


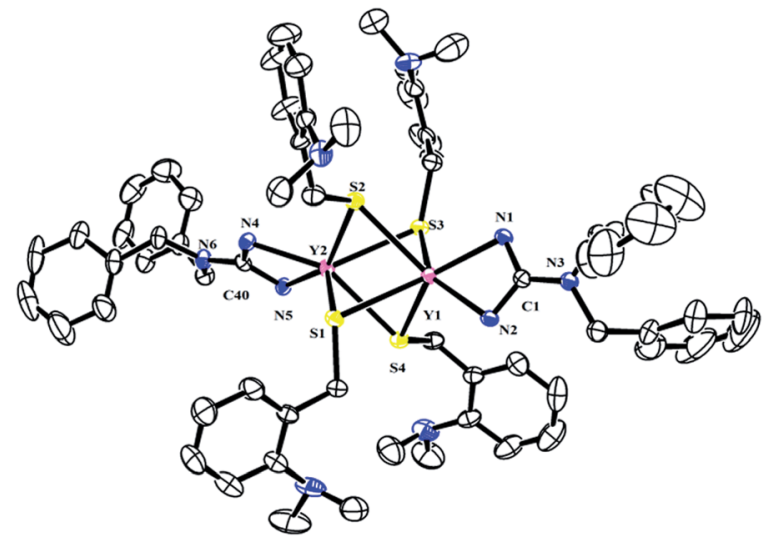

Fig. 4 Molecular structure of complex $4 a$ with thermal ellipsoids at $30 \%$ probability. 2, 6-Diisopropylphenyl groups of guanidinate ligand and all of the hydrogen atoms are omitted for clarity. Selected bond distances $(\AA)$ and angles $\left({ }^{\circ}\right)$ : $Y(1)-N(2) 2.320(3), Y(1)-N(1) 2.338(3), Y(1)-$ $S(3) 2.7781(10), Y(1)-S(4) 2.7900(9), Y(1)-S(2) 2.8012(10), Y(1)-S(1)$ 2.8079(9), $Y(2)-N(4) 2.320(3), Y(2)-N(5) 2.323(3), Y(2)-S(1) 2.7947(10)$, $Y(2)-S(2) 2.795(1), Y(2)-S(4) 2.807(1), Y(2)-S(3)$ 2.8412(9); N(2)-Y(1)$\mathrm{N}(1)$ 56.99(9), S(3)-Y(1)-S(4) 69.31(3), S(4)-Y(1)-S(2) 106.2(1), N(4)$Y(2)-N(5)$ 57.08(9), S(1)-Y(2)-S(2) 69.28(3), S(2)-Y(2)-S(4) 105.9(1), $\mathrm{N}(2)-\mathrm{C}(1)-\mathrm{N}(1) \quad 111.3(3), \quad \mathrm{N}(4)-\mathrm{C}(40)-\mathrm{N}(5) \quad 110.5(3), \quad \mathrm{Y}(2)-\mathrm{S}(1)-\mathrm{Y}(1)$ 73.84(2), $Y(2)-S(2)-Y(1) 73.94(2), Y(1)-S(3)-Y(2)$ 73.58(2), $Y(1)-S(4)-$ $Y(2) 73.93(2)$.

structure is only observed in complex $\left[{ }^{t} \mathrm{BuC}\left(\mathrm{NC}_{6} \mathrm{H}_{3}-2,6-{ }^{i} \mathrm{Pr}_{2}\right)_{2}\right\}$ $\left.\mathrm{Yb}\left(\mu-\mathrm{SCH}_{2} \mathrm{Ph}\right)_{2}\right]_{2}{ }^{11}$ The lengths of $\mathrm{Y}-\mathrm{S}$ bonds range from $2.778(1)$ $\AA$ to 2.841 (1) $\AA$ and are comparable to the previously reported Y$\mathrm{S}\left(\mu_{2}\right.$-SR $)$ bonds. ${ }^{10}$ The dihedral angles between the Y1S1Y2 and Y1S3Y2 plane is $179.7^{\circ}$, indicating that the Y1S1Y2S3 is coplanar. Y1S2Y2S4 unit is also coplanar. Besides, the two planes are almost vertical to each other with a dihedral angle of $89.86^{\circ}$.

\subsection{Reaction of $\left[\left(\mathrm{PhCH}_{2}\right)_{2} \mathrm{NC}\left(\mathrm{NC}_{6} \mathrm{H}_{4}{ }^{i} \mathrm{Pr}_{2}-2,6\right)_{2}\right] \mathrm{RE}$}

$\left(\mathrm{CH}_{2} \mathrm{C}_{6} \mathrm{H}_{4} \mathrm{NMe}_{2}-\mathrm{o}\right)_{2}(\mathrm{RE}=\mathrm{Y}(2 \mathrm{a}), \mathrm{La}(2 \mathrm{~b})$, Dy (2c), Lu (2d)) with PhNCS

The reactivity of complexes 2 towards phenyl isothiocynate was also studied. These reactions provided insertion products $\left[\left(\mathrm{PhCH}_{2}\right)_{2} \mathrm{NC}\left(\mathrm{NC}_{6} \mathrm{H}_{4}{ }^{i} \mathrm{Pr}_{2}-2,6\right)_{2}\right] \mathrm{RE}\left\{\mathrm{SC}\left(\mathrm{CH}_{2} \mathrm{C}_{6} \mathrm{H}_{4} \mathrm{NMe}_{2}-o\right) \mathrm{NPh}\right\}_{2}$ $(\mathrm{THF})_{n}(n=1, \mathrm{RE}=\mathrm{La}(\mathbf{5 b}) ; n=0, \mathrm{RE}=\mathrm{Y}(\mathbf{5 a}), \mathrm{Dy}(\mathbf{5} \mathbf{c}), \mathrm{Lu}(\mathbf{5 d}))$ in $46-77 \%$ yields (Scheme 5 ). Compared to the guanidinate dialkyl complexes 2 , the resonances of methylene protons in aminobenzyl groups of these insertion products shift from upfield to downfield $\delta=4.14$ for $5 \mathbf{a}, 4.17$ for $5 \mathbf{b}$ and 4.15 for 5d ppm respectively. In their ${ }^{13} \mathrm{C}$ NMR spectra, the
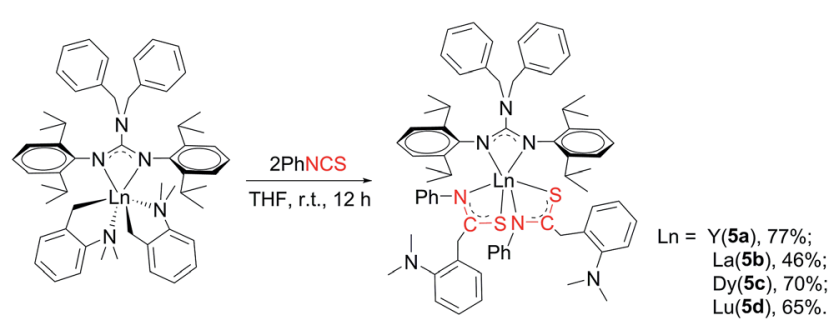

Scheme 5

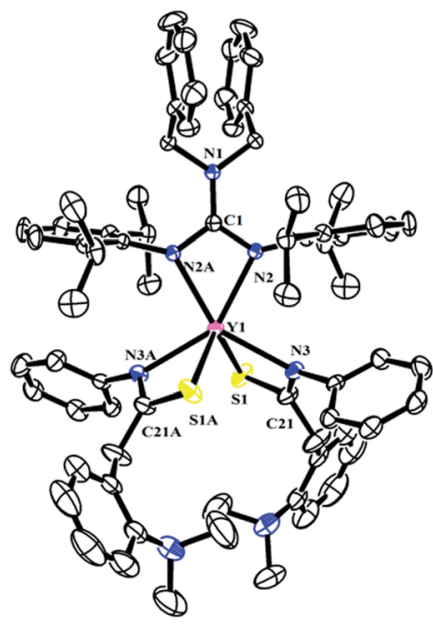

Fig. 5 Molecular structure of complex $5 a$ with thermal ellipsoids at $30 \%$ probability. All of the hydrogen atoms are omitted for clarity. Selected bond distances $(\AA)$ and angles $\left(^{\circ}\right)$ : Y $(1)-N(2 / 2 A) 2.329(2), Y(1)-$ $N(3 / 3 A) 2.405(3), Y(1)-S(1 / 1 A) 2.7154(9), N(1)-C(1) 1.359(5), N(1)-C(2)$ 1.468(3), N(2)-C(1) 1.351(3), S(1)-C(21) 1.735(3), N(3)-C(21) 1.287(4); $N(2)-Y(1)-N(2 A) \quad 56.81(11), N(2)-Y(1)-S(1 A)$ 128.56(6), N(3)-Y(1)-S(1) 60.70(6), N(3)-C(21)-S(1) 118.0(2), N(3A)-Y(1)-N(3) 120.99(12), C(21)$N(3)-Y(1) 99.6(2)$.

corresponding signals were observed at $\delta=42.4(5 \mathbf{a}), 43.2(5 \mathbf{b})$ and $42.6(5 d)$ ppm as singlets. Complex $5 \mathbf{b}$ is of high solubility even in hexane while $\mathbf{5 a}, \mathbf{5 c}$ and $\mathbf{5 d}$ are sparingly soluble in hexane. Noticeably, the larger lanthanum bears one coordinated THF molecule, while complexes 5a, 5c and $\mathbf{5 d}$ are all solvent free mononuclear complexes. As shown in Fig. 5, the yttrium ion of $\mathbf{5 a}$ is surrounded by four nitrogen atoms, two from the guanidinate ligand, two from the NCS fragments and two sulfur atoms from the NCS moieties. The Y-S bond length of 2.7154(9) $\AA$ is identical with the corresponding distances in $1,4-\mathrm{C}_{6} \mathrm{H}_{4}\left[\mathrm{C}(\mathrm{NR})_{2} \mathrm{Y}\left\{\mathrm{SC}\left(\mathrm{CH}_{2} \mathrm{C}_{6} \mathrm{H}_{4} \mathrm{NMe}_{2}-\mathrm{o}\right) \mathrm{NPh}_{2}\right]_{2}\right.$ (ref. $\left.7 a\right)(2.71 \AA)$ and $\left\{\left(\mathrm{CH}_{3} \mathrm{C}_{5} \mathrm{H}_{4}\right)_{2} \mathrm{Y}\left[\eta^{2}-\mathrm{SC}\left(\mathrm{NPh}_{2}\right) \mathrm{NPh}\right]\right\}_{2}(2.7847(8) \AA) .{ }^{12}$ The S1$\mathrm{C} 21$ and N3-C21 distances, 1.735(3) and 1.287(4) Å, are between the corresponding single and double bond lengths, respectively, indicating that the negative charge is delocalized over the $\mathrm{N}-\mathrm{C}-\mathrm{S}$ moiety. ${ }^{13}$

\subsection{Polymerization of isoprene}

Complexes 2 were also evaluated as precatalysts for the polymerization of isoprene, and the results are presented in Table 1. Complexes 2 were inert towards the polymerization of isoprene. The binary system comprised of $2 \mathbf{a}(2 \mathbf{c}$ or $2 \mathbf{d}) /\left[\mathrm{Ph}_{3} \mathrm{C}\right]\left[\mathrm{B}\left(\mathrm{C}_{6} \mathrm{~F}_{5}\right)_{4}\right]$ (1:1) displayed a high catalytic activity and predominant 3,4regioselectivity for isoprene polymerization at room temperature (entries 1 to 4). But significant catalytic activity drop was observed for the lanthanum binary system (entry 2), probably due to the lower Lewis acidity compared to Y, Dy and Lu ions. Molecular weight distributions of all the polymers obtained from these binary systems are very narrow and unimodal (1.031.05) (entries 1 to 8 ). Further kinetics study on yttrium binary system was carried out and displayed in Fig. 6. It is noteworthy that the number-average molecular weight $\left(M_{\mathrm{n}}\right)$ of the yielded 
Table 1 Polymerization of isoprene catalyzed by complexes $2^{a}$

\begin{tabular}{|c|c|c|c|c|c|c|c|c|c|c|}
\hline Entry & Precat. & $\mathrm{Al}$ reagent $\left([\mathrm{Al}]_{\mathrm{o}} /[\mathrm{RE}]_{\mathrm{o}}\right)$ & $t[\mathrm{~min}]$ & $T_{\mathrm{p}}\left[{ }^{\circ} \mathrm{C}\right]$ & $\begin{array}{l}\text { Conversion } \\
{[\%]}\end{array}$ & \multicolumn{3}{|c|}{$\operatorname{Microstructures}^{b}[\%]$} & $M_{\mathrm{n}}\left(\times 10^{4}\right)^{c}$ & $M_{\mathrm{w}} / M_{\mathrm{n}}{ }^{c}$ \\
\hline 2 & $2 \mathbf{b}$ & - & 300 & 25 & 100 & 70 & 11.8 & 18.2 & 7.50 & 1.04 \\
\hline 3 & $2 c$ & - & 12 & 25 & 100 & 83 & 3.9 & 13.1 & 9.04 & 1.03 \\
\hline 4 & $2 d$ & - & 35 & 25 & 100 & 80 & 2.3 & 17.2 & 7.13 & 1.05 \\
\hline 7 & $2 a$ & - & 3 & 25 & 41 & 91 & 2.3 & 6.7 & 3.08 & 1.07 \\
\hline 8 & $2 a$ & - & 2 & 25 & 30 & 91 & 2.3 & 6.7 & 2.38 & 1.05 \\
\hline 9 & $2 a$ & - & 180 & 0 & 100 & 95 & 0.6 & 4.4 & 7.10 & 1.03 \\
\hline 10 & $2 a$ & - & 1440 & -20 & 100 & 99 & 0.6 & 0.3 & 8.43 & 1.06 \\
\hline 11 & $2 a$ & - & 1080 & -20 & 90 & 99 & 0.6 & 0.3 & 7.95 & 1.05 \\
\hline 12 & $2 a$ & - & 720 & -20 & 80 & 99 & 0.6 & 0.3 & 7.04 & 1.03 \\
\hline
\end{tabular}

${ }^{a}$ Conditions: $220 \mu \mathrm{mol},\left[\mathrm{Ph}_{3} \mathrm{C}\right]\left[\mathrm{B}\left(\mathrm{C}_{6} \mathrm{~F}_{5}\right)_{4}\right] 20 \mu \mathrm{mol}$, [IP $]_{0} /[\mathrm{RE}]_{0} 750$, chlorobenzene $10 \mathrm{~mL} .{ }^{b}$ Determined by ${ }^{1} \mathrm{H}$ NMR and ${ }^{13} \mathrm{C}$ NMR spectroscopy in $\mathrm{CDCl}_{3} \cdot{ }^{c}$ Determined by GPC in THF at $40{ }^{\circ} \mathrm{C}$ against polystyrene standard.

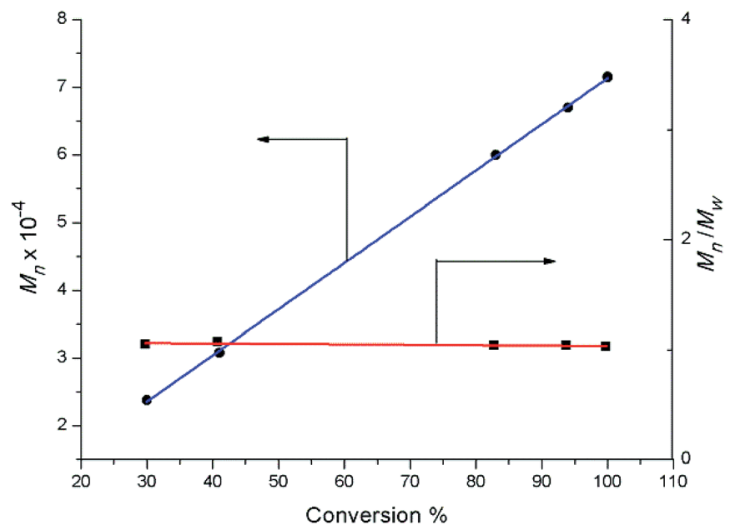

Fig. 6 Polymerization of isoprene with $2 \mathrm{a} /\left[\mathrm{Ph}_{3} \mathrm{C}\right]\left[\mathrm{B}\left(\mathrm{C}_{6} \mathrm{~F}_{5}\right)_{4}\right]$ : molecular weight vs. conversion $\left([Y]_{0}=2.0 \mu \mathrm{mol} \mathrm{mL} \mathrm{m}^{-1},[\mathrm{IP}]_{0} /[\mathrm{Y}]_{0}=750\right.$, chlorobenzene, $25^{\circ} \mathrm{C}$ ).

polymer samples was linearly relative to the conversion. In the meanwhile, the molecular weight distribution $\left(M_{\mathrm{w}} / M_{\mathrm{n}}\right)$ was almost constant (1.03 to 1.07). The kinetics study indicated that the binary system $2 \mathrm{a} /\left[\mathrm{Ph}_{3} \mathrm{C}\right]\left[\mathrm{B}\left(\mathrm{C}_{6} \mathrm{~F}_{5}\right)_{4}\right]$ demonstrated characteristics of living polymerization. To the best of our knowledge, examples of isoprene living polymerization with high 3,4regioselectivity remain relatively rare. ${ }^{14}$ Moreover, the reaction temperature also influenced the polymerization performance. When the polymerization was carried out at $0{ }^{\circ} \mathrm{C}$ (entry 9), the yielded polymer showed the higher proportion of 3,4 units (95\%). At $-20{ }^{\circ} \mathrm{C}$ (entries 10-14), although the activity apparently dropped, it took 24 hours for $2 \mathrm{a} /\left[\mathrm{Ph}_{3} \mathrm{C}\right]\left[\mathrm{B}\left(\mathrm{C}_{6} \mathrm{~F}_{5}\right)_{4}\right]$ system to get $100 \%$ conversion, the higher 3,4-regioselectivity (99\%) was achieved and the yttrium binary system still demonstrates characteristics of living polymerization (Fig. 7). Interestingly, in contrast to the binary system comprised of $2 \mathrm{a} /\left[\mathrm{Ph}_{3} \mathrm{C}\right]\left[\mathrm{B}\left(\mathrm{C}_{6} \mathrm{~F}_{5}\right)_{4}\right]$,

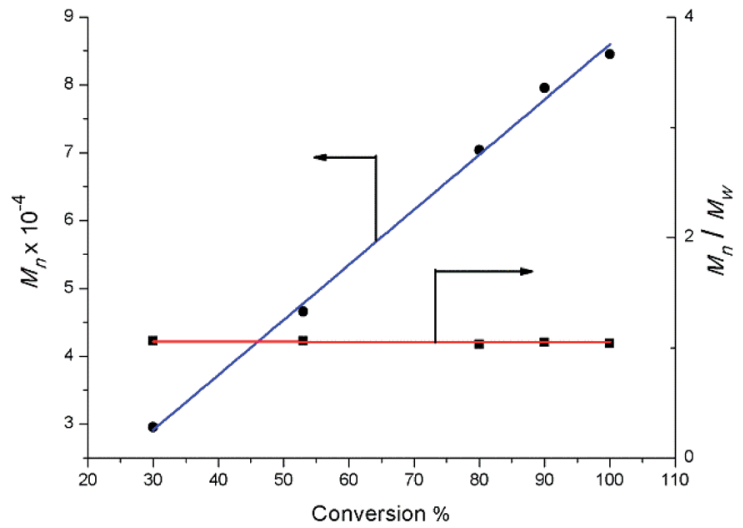

Fig. 7 Polymerization of isoprene with $2 \mathrm{a} /\left[\mathrm{Ph}_{3} \mathrm{C}\right]\left[\mathrm{B}\left(\mathrm{C}_{6} \mathrm{~F}_{5}\right)_{4}\right]$ : molecular weight vs. conversion $\left([Y]_{0}=2.0 \mu \mathrm{mol} \mathrm{mL}{ }^{-1},[I P]_{0} /[Y]_{0}=750\right.$, chlorobenzene, $-20^{\circ} \mathrm{C}$ ).

it was found that the ternary system $2 \mathrm{a} /\left[\mathrm{Ph}_{3} \mathrm{C}\right]\left[\mathrm{B}\left(\mathrm{C}_{6} \mathrm{~F}_{5}\right)_{4}\right] / \mathrm{AlMe}_{3}$ (1:1:5) showed a high cis-1,4-regioselectivity (entry 15). ${ }^{15}$ However, the introduction of $\mathrm{Al}^{\mathrm{i}} \mathrm{Bu}_{3}$ to the $2 \mathrm{a} /\left[\mathrm{Ph}_{3} \mathrm{C}\right]\left[\mathrm{B}\left(\mathrm{C}_{6} \mathrm{~F}_{5}\right)_{4}\right]$ system led to the formation of polymer blend (entry 16).

\section{Conclusions}

In summary, a series of neutral mono(guanidinate) rare-earth bis(alkyl) complexes have been synthesized via the protonolysis reaction of homoleptic rare-earth alkyl complexes with one equimolar amount of a new bulky guanidine. The reactions of bis(aminobenzyl) complexes with $\mathrm{CO}_{2}, \mathrm{~S}_{8}$ and $\mathrm{PhNCS}$ provide some new options for effective synthetic routes for guanidinate lanthanide derivatives. Moreover, upon activation of an organoborate, such as $\left[\mathrm{Ph}_{3} \mathrm{C}\right]\left[\mathrm{B}\left(\mathrm{C}_{6} \mathrm{~F}_{5}\right)_{4}\right]$, complexes 2 show excellent activity and predominant 3,4-selectivity towards isoprene 
polymerization in a living fashion, whereas the ternary system $2 \mathbf{a} /\left[\mathrm{Ph}_{3} \mathrm{C}\right]\left[\mathrm{B}\left(\mathrm{C}_{6} \mathrm{~F}_{5}\right)_{4}\right] / \mathrm{AlMe}_{3}(1: 1: 5)$ showed a high cis-1,4regioselectivity.

\section{Experiment section}

\subsection{Materials and general procedures}

All manipulations involving air- and moisture sensitive compounds were performed under an inert atmosphere of purified nitrogen with rigorous exclusion of air and moisture using standard Schlenk techniques and a nitrogen filled glove box operating at less than $1 \mathrm{ppm}$ oxygen and $1 \mathrm{ppm}$ moisture. Solvents (toluene, hexane, and THF) were distilled from sodium/benzophenone ketyl, and dried over fresh $\mathrm{Na}$ chips in the glove box. Bis(2,6-diisopropylphenyl)carbodiimide was obtained from Tokyo Chemical Industry Co., Ltd and used without purification. $\mathrm{CH}_{3} \mathrm{C}_{6} \mathrm{H}_{4} \mathrm{NMe}_{2}-\mathrm{O}$ was purchased from Acros and used without purification. ${ }^{n} \mathrm{BuLi}\left(2.5 \mathrm{~mol} \mathrm{~L}^{-1}\right.$ in hexane), $\mathrm{AlMe}_{3}$ ( $1 \mathrm{~mol} \mathrm{~L}^{-1}$ in hexane) and $\mathrm{Al}^{i} \mathrm{Bu}_{3}\left(1 \mathrm{~mol} \mathrm{~L}^{-1}\right.$ in hexane) were purchased from J\&K and used without purification. Phenyl isothiocyanate were purchased from Dar Rui and distilled from $\mathrm{CaH}_{2}$ before being used. Highly pure $\mathrm{CO}_{2}$ gas (99.99\%) was purchased from Pujiang Gas and dried by passing through activated $4 \AA$ molecular sieves. Isoprene was obtained from Tokyo Chemical Industry Co., Ltd and purified by distillation over $\mathrm{CaH}_{2}$ under a nitrogen atmosphere. $\mathrm{C}_{6} \mathrm{D}_{6}$ and $\mathrm{CDCl}_{3}$ was obtained from Cambridge Isotope and dried by sodium chips. $\mathrm{RE}\left(\mathrm{CH}_{2} \mathrm{C}_{6} \mathrm{H}_{4} \mathrm{NMe}_{2}-\mathrm{o}\right)_{3}$ (ref. 16) were prepared according to the literature procedures. ${ }^{1} \mathrm{H}$ NMR and ${ }^{13} \mathrm{C}$ NMR spectra were recorded on a JEOL ECA-400 NMR spectrometer (FT, $400 \mathrm{MHz}$ for ${ }^{1} \mathrm{H} ; 100 \mathrm{MHz}$ for ${ }^{13} \mathrm{C}$ ) in $\mathrm{C}_{6} \mathrm{D}_{6}$ at room temperature. GPC data were collected on a Waters 1515 Breeze GPC system using a polystyrene standard in THF.

\subsection{X-ray crystallographic analysis}

Suitable crystals were sealed in thin-wall glass capillaries under a microscope in the glove box. Data collections were performed on a Bruker SMART APEX diffractometer with a CCD area detector using graphite-monochromated MoK $\alpha$ radiation $(\lambda=$ $0.71073 \AA$ ). The determination of crystal class and unit cell was carried out by the SMART program package. The raw frame data were processed using SAINT $^{17}$ and SADABS $^{18}$ to yield the reflection data file. The structure was solved by using SHELXTL program. ${ }^{19}$ Refinement was performed on $F^{2}$ anisotropically by the full-matrix least-squares method for all the non-hydrogen atoms. The analytical scattering factors for neutral atoms were used throughout the analysis. Except for the hydrogen atoms on bridging-carbons, hydrogen atoms were placed at the calculated positions and included in the structure calculation without further refinement of the parameters. The hydrogen atoms on bridging carbons were located by difference Fourier syntheses and their coordinates and isotropic parameters were refined. The disordered toluene and THF molecules within the crystal lattice are not crystallographically well defined and are squeezed by the PLATON program. Details of this SQUEEZE are given in the cif files. Residual electron densities were of no chemical significance. Crystal data, data collection, and processing parameters for complexes $\mathbf{2 b}, \mathbf{3 a}, \mathbf{4 a}$ and $\mathbf{5 a}$ are summarized in Table 2. CCDC - 1542242 (1), 893571 (2d), 1541968 (3a), 1541967 (3b), 1541964 (3c), 1541970 (3d), 1541962

Table 2 Crystallographic data for complexes 2d, 3a, 4a, 5a

\begin{tabular}{|c|c|c|c|c|}
\hline & $2 d$ & $3 a$ & $4 a$ & $5 a$ \\
\hline Formula & $\mathrm{C}_{57} \mathrm{H}_{72} \mathrm{LuN}_{5}$ & $\mathrm{C}_{59} \mathrm{H}_{72} \mathrm{~N}_{5} \mathrm{O}_{4} \mathrm{Y}$ & $\mathrm{C}_{114} \mathrm{H}_{144} \mathrm{~N}_{10} \mathrm{~S}_{4} \mathrm{Y}_{2}$ & $\mathrm{C}_{71} \mathrm{H}_{82} \mathrm{~N}_{7} \mathrm{~S}_{2} \mathrm{Y}$ \\
\hline Formula weight & 1002.17 & 1004.13 & 1960.44 & 1186.47 \\
\hline Temperature (K) & $293(2)$ & $296(2)$ & $273(2)$ & $296(2)$ \\
\hline Wavelength $(\AA)$ & 0.71073 & 0.71073 & 0.71073 & 0.71073 \\
\hline Crystal system & Rhombohedral & Triclinic & Monoclinic & Monoclinic \\
\hline Space group & $R \overline{3} c$ & $P \overline{1}$ & $P 21 / n$ & $C 2 / c$ \\
\hline$a(\AA)$ & 24.986(7) & $13.041(5)$ & $15.488(2)$ & $13.050(2)$ \\
\hline$b(\AA)$ & $24.986(7)$ & $16.053(6)$ & $23.909(3)$ & $26.302(5)$ \\
\hline$c(\AA)$ & $47.359(9)$ & $16.979(11)$ & $31.418(4)$ & $19.537(4)$ \\
\hline$\alpha(\mathrm{deg})$ & 90 & $103.789(10)$ & 90 & 90 \\
\hline$\beta$ (deg) & 90 & $104.711(10)$ & $98.781(2)$ & $104.170(3)$ \\
\hline$\gamma(\mathrm{deg})$ & 120 & $112.479(7)$ & 90 & 90 \\
\hline$V\left(\AA^{3}\right)$ & $13025(9)$ & $2945(3)$ & $11497(3)$ & $6502(2)$ \\
\hline$Z$ & 18 & 2 & 4 & 4 \\
\hline$\mu\left(\mathrm{mm}^{-1}\right)$ & 1.771 & 1.036 & 1.125 & 1.007 \\
\hline$F(000)$ & 9360 & 1064 & 4160 & 2512 \\
\hline$\theta$ range $\left(^{\circ}\right)$ & 1.63 to 25.50 & 1.48 to 25.05 & 1.075 to 25.050 & 1.79 to 25.04 \\
\hline \multirow[t]{3}{*}{$h, k, l$ range } & $-24 \leq h \leq 30$ & $-15 \leq h \leq 15$ & $-18 \leq h \leq 18$ & $-15 \leq h \leq 14$ \\
\hline & $-29 \leq k \leq 30$ & $-19 \leq k \leq 18$ & $-28 \leq k \leq 24$ & $-29 \leq k \leq 31$ \\
\hline & $-57 \leq l \leq 56$ & $-14 \leq l \leq 20$ & $-28 \leq l \leq 37$ & $-23 \leq l \leq 23$ \\
\hline Reflections collected & 27469 & 16741 & 56587 & 19415 \\
\hline Reflections unique & $5296[R(\mathrm{int})=0.0484]$ & $10159[R(\mathrm{int})=0.0594]$ & $20283[R(\mathrm{int})=0.0538]$ & $5746[R(\mathrm{int})=0.0538]$ \\
\hline Goodness-of-fit on $F^{2}$ & 1.002 & 1.044 & 1.042 & 1.032 \\
\hline Final $R$ indices $[I>2 \sigma(I)]$ & $R_{1}=0.0600, \mathrm{w} R_{2}=0.1539$ & $R_{1}=0.0819, \mathrm{w} R_{2}=0.2077$ & $R_{1}=0.0491, \mathrm{w} R_{2}=0.1116$ & $R_{1}=0.0440, \mathrm{w} R_{2}=0.1154$ \\
\hline$R$ indices (all data) & $R_{1}=0.1189, \mathrm{w} R_{2}=0.1834$ & $R_{1}=0.1219, \mathrm{w} R_{2}=0.2282$ & $R_{1}=0.0915, \mathrm{w} R_{2}=0.1212$ & $R_{1}=0.0702, \mathrm{w} R_{2}=0.1348$ \\
\hline
\end{tabular}


(4a), 1541966 (4c), 1541963 (4d), 1541969 (5a), 1541965 (5c), 1541961 (5d) contain the supplementary crystallographic data for this paper. $\dagger$

\subsection{Synthesis of $\left(\mathrm{PhCH}_{2}\right)_{2} \mathrm{~N}[\mathrm{C}(\mathrm{NHR})=(\mathrm{NR})]\left(\mathrm{R}=2,6^{i}{ }^{i} \mathrm{Pr}_{2}-\right.$ $\left.\mathrm{C}_{6} \mathrm{H}_{3}\right)$ (1)}

A ${ }^{n}$ BuLi solution (10.0 mmol, $4 \mathrm{~mL}, 2.5 \mathrm{M}$ in hexane) was added slowly to a stirred solution of $\left(\mathrm{PhCH}_{2}\right)_{2} \mathrm{NH}(1.97 \mathrm{~g}, 10.0 \mathrm{mmol})$ in THF (30 mL) at room temperature, then stirred for $2 \mathrm{~h}$. Subsequently, the solution of the in situ $\left(\mathrm{PhCH}_{2}\right)_{2} \mathrm{NLi}$ was added to a stirred THF solution of bis(2,6-diisopropylphenyl) carbodiimide $(3.63 \mathrm{~g}, 10.0 \mathrm{mmol})$ at room temperature, the mixture was stirred for $4 \mathrm{~h}$ and added slowly the distilled water to afford a clear orange solution. All volatiles were removed under vacuum. The residue was washed with water, and the product was extracted with hexane $(3 \times 25 \mathrm{~mL})$, all volatiles were removed under vacuum, and the yellowish powder was recrystallized in hexane at $-35{ }^{\circ} \mathrm{C}$ to give colourless crystals (4.53 g, 81\%). ${ }^{1} \mathrm{H}$ NMR (400 $\left.\mathrm{MHz}, \mathrm{CDCl}_{3}, 25{ }^{\circ} \mathrm{C}\right): 7.25-6.97$ (m, $16 \mathrm{H}, \mathrm{Ar}), 5.17(\mathrm{~s}, 1 \mathrm{H},-\mathrm{NH}-), 4.29\left(\mathrm{~s}, 4 \mathrm{H},-\mathrm{CH}_{2} \mathrm{Ph}\right), 3.31-3.20(\mathrm{~m}$, $4 \mathrm{H},-\mathrm{CHMe}$ ), 1.34 (d, $\left.J=8 \mathrm{~Hz}, 6 \mathrm{H},-\mathrm{CHMe})_{2}\right), 1.25$ (d, $J=8 \mathrm{~Hz}$, $6 \mathrm{H},-\mathrm{CHMe}_{2}$ ), 1.03 (d, $\left.J=8 \mathrm{~Hz}, 6 \mathrm{H},-\mathrm{CHMe} e_{2}\right), 0.91$ (d, $J=8 \mathrm{~Hz}$, $\left.6 \mathrm{H},-\mathrm{CHMe} e_{2}\right),{ }^{13} \mathrm{C}$ NMR $\left(100 \mathrm{MHz}, \mathrm{CDCl}_{3}, 25{ }^{\circ} \mathrm{C}\right): \delta=149.8$ $(\mathrm{NCN}), 146.0(\mathrm{Ar}), 144.7$ (Ar), $140.2(\mathrm{Ar}), 138.6(\mathrm{Ar}), 128.7(\mathrm{Ar})$, 128.2 (Ar), 127.3 (Ar), 123.0 (Ar), 122.5 (Ar), $51.0\left(-\mathrm{CH}_{2} \mathrm{Ph}\right), 29.0$ $\left.\left(-\mathrm{CHMe}_{2}\right), 28.4\left(-\mathrm{CHMe}_{2}\right), 25.6(-\mathrm{CHMe})_{2}\right), 24.6\left(-\mathrm{CHMe} e_{2}\right), 22.6$ $\left(-\mathrm{CHMe}_{2}\right), 21.9\left(-\mathrm{CHMe} e_{2}\right) ;{ }^{1} \mathrm{H}$ NMR $\left(400 \mathrm{MHz}, \mathrm{C}_{6} \mathrm{D}_{6}, 25{ }^{\circ} \mathrm{C}\right): 7.28$ (s, 1H, Ar), 7.26 (s, 1H, Ar), 7.14-7.09 (m, 9H, Ar), 7.06-7.03 (m, $3 \mathrm{H}, \mathrm{Ar}), 6.95$ (s, 1H, Ar), 6,94 (s, 1H, Ar), 5.40 (s, 1H, -NH-), 4.43 (s, $\left.4 \mathrm{H},-\mathrm{CH}_{2} \mathrm{Ph}\right), 3.50\left(\mathrm{~m}, 2 \mathrm{H},-\mathrm{CHMe}\right.$ ), $3.35\left(\mathrm{~m}, 2 \mathrm{H},-\mathrm{CHMe}_{2}\right)$, 1.42 (d, $J=4 \mathrm{~Hz}, 6 \mathrm{H},-\mathrm{CHMe}$ ), 1.38 (d, J=8 Hz, 6H, $-\mathrm{CHMe}_{2}$ ), 1.03 (d, $J=4 \mathrm{~Hz}, 6 \mathrm{H},-\mathrm{CHMe}$ ), 0.83 (d, $J=4 \mathrm{~Hz}, 6 \mathrm{H},-\mathrm{CHMe}_{2}$ ), ${ }^{13} \mathrm{C}$ NMR $\left(100 \mathrm{MHz}, \mathrm{C}_{6} \mathrm{D}_{6}, 25{ }^{\circ} \mathrm{C}\right): \delta=150.1(\mathrm{NCN}), 146.1(\mathrm{Ar})$, 145.1 (Ar), 140.3 (Ar), 138.9 (Ar), 135.5 (Ar), 128.8 (Ar), 128.5 (Ar), 127.2 (Ar), 124.1 (Ar), 123.5 (Ar), $123.4(\mathrm{Ar}), 51.5\left(-\mathrm{CH}_{2} \mathrm{Ph}\right), 29.3$ $\left.\left(-\mathrm{CHMe}_{2}\right), 28.6\left(-\mathrm{CHMe}_{2}\right), 25.6\left(-\mathrm{CHMe}_{2}\right), 24.9(-\mathrm{CHMe})_{2}\right), 22.7$ $\left(-\mathrm{CHMe} e_{2}\right), 22.0\left(-\mathrm{CHMe} e_{2}\right)$. Calcd for $\mathrm{C}_{39} \mathrm{H}_{49} \mathrm{~N}_{3}(\%): \mathrm{C}, 83.67 ; \mathrm{H}$, 8.82; N, 7.51; found: C, 83.96; H, 8.77; N, 7.48.

\subsection{Synthesis of $\left[\left(\mathrm{PhCH}_{2}\right)_{2} \mathrm{NC}\left(\mathrm{NC}_{6} \mathrm{H}_{4}{ }^{i} \mathrm{Pr}_{2}-2,6\right)_{2}\right]$ $\mathrm{Y}\left(\mathrm{CH}_{2} \mathrm{C}_{6} \mathrm{H}_{4} \mathrm{NMe}_{2}-\mathrm{o}\right)_{2}$ (2a)}

A THF solution $(10 \mathrm{~mL})$ of $\mathrm{Y}\left(\mathrm{CH}_{2} \mathrm{C}_{6} \mathrm{H}_{4} \mathrm{NMe}_{2}-O\right)_{3}(0.25 \mathrm{~g}, 0.5$ $\mathrm{mmol})$ was added into a stirred solution $(20 \mathrm{~mL})$ of $\left(\mathrm{PhCH}_{2}\right)_{2} \mathrm{~N}$ $[\mathrm{C}(\mathrm{NHR})=(\mathrm{NR})]\left(\mathrm{R}=2,6{ }^{i} \mathrm{Pr}_{2}-\mathrm{C}_{6} \mathrm{H}_{3}\right)(\mathbf{1})(0.28 \mathrm{~g}, 0.5 \mathrm{mmol})$ in THF. The reaction solution was left to stir for 3.5 days at $65^{\circ} \mathrm{C}$ and all volatiles were removed under vacuum. The oily residue was washed with cold hexane and pale yellow powder was obtained by filtration. The pale yellow powder was recrystallized in toluene at $-35{ }^{\circ} \mathrm{C}$ for 2 days to give white powder of $2 \mathrm{a} 0.30 \mathrm{~g}$ (65\%). ${ }^{1} \mathrm{H}$ NMR $\left(400 \mathrm{MHz}, \mathrm{C}_{6} \mathrm{D}_{6}, 25{ }^{\circ} \mathrm{C}\right): \delta=7.15-7.13(\mathrm{~m}, 4 \mathrm{H}$, Ar), 7.02-6.86 (m, 12H, Ar), 6.68 (d, $J=8 \mathrm{~Hz}, 4 \mathrm{H}, \mathrm{Ar}), 6.59$ (d, $J=$ $12 \mathrm{~Hz}, 2 \mathrm{H}, \mathrm{Ar}), 6.95-6.87$ (m, 10H, Ar), 6.75-6.73 (m, 4H, Ar), $6.68(\mathrm{~d}, J=8 \mathrm{~Hz}, 4 \mathrm{H}, \mathrm{Ar}), 6.52(\mathrm{~m}, 2 \mathrm{H}, \mathrm{Ar}), 4.28$ (br s, $4 \mathrm{H}$, $-\mathrm{CH}_{2} \mathrm{Ph}$ ), $4.12\left(\mathrm{~m}, 4 \mathrm{H},-\mathrm{CHMe} \mathrm{M}_{2}\right), 2.19$ (s, 12H, $\left.-\mathrm{NMe} e_{2}\right), 1.81$ (s, $4 \mathrm{H},-\mathrm{CH}_{2} \mathrm{C}_{6} \mathrm{H}_{4} \mathrm{NMe}_{2}-\mathrm{o}$ ), 1.50 (d, $\left.J=6 \mathrm{~Hz}, 12 \mathrm{H},-\mathrm{CHMe} e_{2}\right), 1.45$ (d, $\left.J=4 \mathrm{~Hz}, 12 \mathrm{H},-\mathrm{CHMe} e_{2}\right),{ }^{13} \mathrm{C} \mathrm{NMR}\left(100 \mathrm{MHz}, \mathrm{C}_{6} \mathrm{D}_{6}, 25{ }^{\circ} \mathrm{C}\right): \delta=$
$161.3(\mathrm{NCN}), 145.4$ (d, $J=26 \mathrm{~Hz}, \mathrm{Ar}), 144.2$ (s, Ar), 141.8 (s, Ar), 136.0 (s, Ar), 129.9 (s, Ar), 127.4 (s, Ar), 126.7 (s, Ar), 124.4 (s, Ar), 123.8 (s, Ar), 120.8 (s, Ar), 118.2 (s, Ar), 53.2 (s, $\left.-\mathrm{CH}_{2} \mathrm{Ph}\right), 48.0$ (d, $J=20 \mathrm{~Hz},-\mathrm{CH}_{2} \mathrm{C}_{6} \mathrm{H}_{4} \mathrm{NMe}_{2}-\mathrm{o}$ ), 46.6 (br s, $-\mathrm{NMe} e_{2}$ ), 29.1 (s, $-\mathrm{CHMe}_{2}$ ), 24.7 (s, $-\mathrm{CHMe}$ ), 24.2 (br s, $-\mathrm{CHMe}$ ). Calcd for $\mathrm{C}_{57} \mathrm{H}_{72} \mathrm{~N}_{5} \mathrm{Y}$ (\%): C, 74.73; H, 7.92; N, 7.64; found: C, 75.25; $\mathrm{H}$, 7.76; N, 7.20.

\subsection{Synthesis of $\left[\left(\mathrm{PhCH}_{2}\right)_{2} \mathrm{NC}\left(\mathrm{NC}_{6} \mathrm{H}_{4}{ }^{i} \mathrm{Pr}_{2}-2,6\right)_{2}\right]$ $\mathrm{La}\left(\mathrm{CH}_{2} \mathrm{C}_{6} \mathrm{H}_{4} \mathrm{NMe}_{2}-\mathrm{o}\right)_{2}$ (2b)}

A THF solution $(10 \mathrm{~mL})$ of $\mathrm{La}\left(\mathrm{CH}_{2} \mathrm{C}_{6} \mathrm{H}_{4} \mathrm{NMe}_{2}-\mathrm{o}\right)_{3}(0.27 \mathrm{~g}, 0.5$ $\mathrm{mmol})$ was added into a stirred THF solution $(20 \mathrm{~mL})$ of $\left(\mathrm{PhCH}_{2}\right)_{2} \mathrm{~N}[\mathrm{C}(\mathrm{NHR})=(\mathrm{NR})]\left(\mathrm{R}=2,6-{ }^{i} \mathrm{Pr}_{2}-\mathrm{C}_{6} \mathrm{H}_{3}\right)(\mathbf{1})(0.280 \mathrm{~g}, 0.5$ $\mathrm{mmol})$. The reaction solution was left to stir for 12 hours at $50{ }^{\circ} \mathrm{C}$ and all volatiles were removed under vacuum. The oily residue was washed with cold hexane and yellow powder was obtained by filtration. The powder was recrystallized in toluene at $-35{ }^{\circ} \mathrm{C}$ for 3 days to give yellow powder of $2 \mathrm{~b} 0.21 \mathrm{~g}(43 \%) .{ }^{1} \mathrm{H}$ NMR (400 MHz, $\left.\mathrm{C}_{6} \mathrm{D}_{6}, 25{ }^{\circ} \mathrm{C}\right): \delta=7.14(\mathrm{~s}, 2 \mathrm{H}, \operatorname{Ar}), 7.12(\mathrm{~s}, 2 \mathrm{H}$, Ar), 6.99 (s, 1H, Ar), 6.97 (s, 1H, Ar), 6.95-6.87 (m, 10H, Ar), 6.75$6.73(\mathrm{~m}, 4 \mathrm{H}, \mathrm{Ar}), 6.68(\mathrm{~s}, 1 \mathrm{H}, \mathrm{Ar}), 6.66(\mathrm{~s}, 1 \mathrm{H}, \mathrm{Ar}), 6.61-6.58(\mathrm{~m}$, $2 \mathrm{H}, \mathrm{Ar}), 4.18\left(\mathrm{~s}, 4 \mathrm{H},-\mathrm{CH}_{2} \mathrm{Ph}\right), 3.93\left(\mathrm{~m}, 4 \mathrm{H},-\mathrm{CHMe} \mathrm{M}_{2}\right), 2.06(\mathrm{~s}$, $12 \mathrm{H},-\mathrm{NMe}_{2}$ ), $1.84\left(\mathrm{~s}, 4 \mathrm{H},-\mathrm{CH}_{2} \mathrm{C}_{6} \mathrm{H}_{4} \mathrm{NMe}_{2}-\mathrm{o}\right), 1.42$ (d, $J=8 \mathrm{~Hz}$, $\left.12 \mathrm{H},-\mathrm{CHMe}_{2}\right), 1.35$ (d, $\left.J=8 \mathrm{~Hz}, 12 \mathrm{H},-\mathrm{CHMe} e_{2}\right),{ }^{13} \mathrm{C} \mathrm{NMR}(100$ $\left.\mathrm{MHz}, \mathrm{C}_{6} \mathrm{D}_{6}, 25{ }^{\circ} \mathrm{C}\right): \delta=158.4(\mathrm{NCN}), 145.1(\mathrm{~s}, \mathrm{Ar}), 143.8(\mathrm{~s}, \mathrm{Ar})$, 141.1 (s, Ar), 141.0 (s, Ar), 136.4 (s, Ar), 130.0 (s, Ar), 129.3 (s, Ar), 128.6 (s, Ar), 128.0 (s, Ar), 127.6 (s, Ar), 127.4 (s, Ar), 124.2 (s, Ar), 122.9 (s, Ar), 119.7 (s, Ar), 119.3 (s, Ar), 61.6 (s, $-C_{2} \mathrm{C}_{6} \mathrm{H}_{4} \mathrm{NMe}_{2}-$ o), $52.4\left(\mathrm{~s},-\mathrm{CH}_{2} \mathrm{Ph}\right), 44.8\left(\mathrm{~s},-\mathrm{NMe} \mathrm{e}_{2}\right), 29.1$ (s, $\left.-\mathrm{CHMe}_{2}\right), 24.6$ (s, $-\mathrm{CHMe}_{2}$ ), 24.1 (s, $-\mathrm{CHMe}$ ). Calcd for $\mathrm{C}_{57} \mathrm{H}_{72} \mathrm{~N}_{5} \mathrm{La}(\%)$ : C, 70.86; $\mathrm{H}, 7.51 ; \mathrm{N}, 7.25$; found: C, 70.71; H, 7.43; N, 6.89.

\subsection{Synthesis of $\left[\left(\mathrm{PhCH}_{2}\right)_{2} \mathrm{NC}\left(\mathrm{NC}_{6} \mathrm{H}_{4}{ }^{i} \mathrm{Pr}_{2}-2,6\right)_{2}\right]$ $\operatorname{Dy}\left(\mathrm{CH}_{2} \mathrm{C}_{6} \mathrm{H}_{4} \mathrm{NMe}_{2}-\mathrm{o}\right)_{2}(2 \mathrm{c})$}

A THF solution $(10 \mathrm{~mL})$ of $\mathrm{Dy}\left(\mathrm{CH}_{2} \mathrm{C}_{6} \mathrm{H}_{4} \mathrm{NMe}_{2}-\mathrm{O}\right)_{3}(0.28 \mathrm{~g}, 0.5$ mmol) was added into a stirred solution $(20 \mathrm{~mL})$ of $\left(\mathrm{PhCH}_{2}\right)_{2} \mathrm{~N}$ $[\mathrm{C}(\mathrm{NHR})=(\mathrm{NR})]\left(\mathrm{R}=2,6{ }^{i} \mathrm{Pr}_{2}-\mathrm{C}_{6} \mathrm{H}_{3}\right)(1)(0.28 \mathrm{~g}, 0.5 \mathrm{mmol})$ in THF. The reaction solution was left to stir for 3 days at $65{ }^{\circ} \mathrm{C}$, and all volatiles were removed under vacuum. The oily residue was washed with cold hexane and pale yellow powder was obtained by filtration. The powder was recrystallized in toluene at $-35{ }^{\circ} \mathrm{C}$ for 2 days to give pale yellow powder of $2 \mathrm{c} 0.29 \mathrm{~g}(58 \%)$. Calcd for $\mathrm{C}_{57} \mathrm{H}_{72} \mathrm{~N}_{5} \mathrm{Dy}(\%)$ : C, 69.17; H, 7.33; N, 7.08; found: C, $69.25 ; \mathrm{H}, 7.83 ; \mathrm{N}, 6.71$.

\subsection{Synthesis of $\left[\left(\mathrm{PhCH}_{2}\right)_{2} \mathrm{NC}\left(\mathrm{NC}_{6} \mathrm{H}_{4}{ }^{i} \mathrm{Pr}_{2}-2,6\right)_{2}\right]$ $\mathrm{Lu}\left(\mathrm{CH}_{2} \mathrm{C}_{6} \mathrm{H}_{4} \mathrm{NMe}_{2}-o\right)_{2}(2 \mathrm{~d})$}

A THF solution $(10 \mathrm{~mL})$ of $\mathrm{Lu}\left(\mathrm{CH}_{2} \mathrm{C}_{6} \mathrm{H}_{4} \mathrm{NMe}_{2}-\mathrm{o}\right)_{3}(0.29 \mathrm{~g}, 0.5$ $\mathrm{mmol})$ was added into a stirred THF solution $(20 \mathrm{~mL})$ of

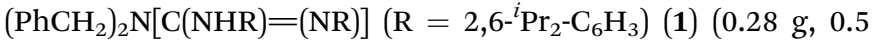
$\mathrm{mmol})$. The reaction solution was left to stir for 3.5 days at $65{ }^{\circ} \mathrm{C}$ and all volatiles were removed under vacuum. The oily residue was washed with cold hexane and white powder was obtained by filtration. The white powder was recrystallized in toluene at $-35{ }^{\circ} \mathrm{C}$ for 2 days to give a colourless crystalline complex $2 \mathrm{~d}$ $0.23 \mathrm{~g}(45 \%) .{ }^{1} \mathrm{H}$ NMR $\left(400 \mathrm{MHz}, \mathrm{C}_{6} \mathrm{D}_{6}, 25{ }^{\circ} \mathrm{C}\right): \delta=7.14-7.12(\mathrm{~m}$, 
$4 \mathrm{H}, \mathrm{Ar}), 7.00-6.96(\mathrm{~m}, 8 \mathrm{H}, \mathrm{Ar}), 6.90-6.84(\mathrm{~m}, 8 \mathrm{H}, \mathrm{Ar}), 6.97$ (s, 1H, Ar), 6.95-6.87 (m, 10H, Ar), 6.75-6.73 (m, 4H, Ar), 6.68 (d, $J=$ $8 \mathrm{~Hz}, 4 \mathrm{H}, \mathrm{Ar}$ ), 6.52 (m, 4H, Ar), 4.31 (br s, $\left.4 \mathrm{H},-\mathrm{CH}_{2} \mathrm{Ph}\right), 4.20$ (m, $4 \mathrm{H},-\mathrm{CHMe}$ ), $2.21\left(\mathrm{~s}, 12 \mathrm{H},-\mathrm{NMe}_{2}\right), 1.80\left(\mathrm{~s}, 4 \mathrm{H},-\mathrm{CH}_{2} \mathrm{C}_{6} \mathrm{H}_{4} \mathrm{NMe}_{2}-\right.$ $o$ ), 1.53 (d, $J=12 \mathrm{~Hz}, 12 \mathrm{H},-\mathrm{CHMe}_{2}$ ), 1.47 (d, $J=8 \mathrm{~Hz}, 12 \mathrm{H}$, $\left.-\mathrm{CHMe} e_{2}\right),{ }^{13} \mathrm{C}$ NMR $\left(100 \mathrm{MHz}, \mathrm{C}_{6} \mathrm{D}_{6}, 25{ }^{\circ} \mathrm{C}\right): \delta=161.8(\mathrm{NCN})$, 145.7 (s, Ar), 145.5 (s, Ar), 142.3 (s, Ar), 136.0 (s, Ar), 129.9 (s, Ar), 127.4 (s, Ar), 126.3 (s, Ar), 124.5 (s, Ar), 124.2 (s, Ar), 121.2 (s, Ar), 117.8 (s, Ar), 53.4 (s, $\left.-\mathrm{CH}_{2} \mathrm{Ph}\right), 53.3$ (s, $\left.-\mathrm{CH}_{2} \mathrm{C}_{6} \mathrm{H}_{4} \mathrm{NMe}_{2}-\mathrm{o}\right), 47.2$ $\left(\mathrm{s},-\mathrm{NMe}_{2}\right), 28.9\left(\mathrm{~s},-\mathrm{CHMe}_{2}\right), 25.1\left(\mathrm{~s},-\mathrm{CHMe} e_{2}\right), 24.4$ (s, $-\mathrm{CHMe}$ ). Calcd for $\mathrm{C}_{57} \mathrm{H}_{72} \mathrm{LuN}_{5}$ (\%): C, 68.31; H, 7.24; N, 6.99; found: C, 69.01; H, 7.19; N, 6.72.

\subsection{Synthesis of $\left\{\left[\left(\mathrm{PhCH}_{2}\right)_{2} \mathrm{NC}\left(\mathrm{NC}_{6} \mathrm{H}_{4}{ }^{i} \mathrm{Pr}_{2}-2,6\right)_{2}\right] \mathrm{Y}\left(\mu-\eta^{2}: \eta^{1}-\right.\right.$ $\left.\left.\mathrm{O}_{2} \mathrm{CCH}_{2} \mathrm{C}_{6} \mathrm{H}_{4} \mathrm{NMe}_{2}-\sigma\right)\left(\mu-\eta^{1}: \eta^{1}-\mathrm{O}_{2} \mathrm{CCH}_{2} \mathrm{C}_{6} \mathrm{H}_{4} \mathrm{NMe}_{2}-o\right)\right\}_{2}$ (3a)}

A THF $(10 \mathrm{~mL})$ solution of complex $2 \mathrm{a}(0.46 \mathrm{~g}, 0.5 \mathrm{mmol})$ was placed in a tube with a Teflon stopcock and degassed by a freeze pump thaw cycle. One atmospheres of $\mathrm{CO}_{2}$ was introduced into the tube and the solution was concentrated to saturation after 10 minutes. Colourless crystals of $3 \mathrm{a}(0.45 \mathrm{~g}, 90 \%)$ were harvested after the solution stood at ambient temperature for 3 days. ${ }^{1} \mathrm{H}$ NMR $\left(400 \mathrm{MHz}, \mathrm{C}_{6} \mathrm{D}_{6}, 25^{\circ} \mathrm{C}\right): \delta=7.18-7.12(\mathrm{~m}, 8 \mathrm{H}, \mathrm{Ar})$, 6.98 (br s, 14H, Ar), 6.94-6.87 (m, 18H, Ar), 6.71-6.69 (m, 8H, $\mathrm{Ar}), 4.14\left(\mathrm{~s}, 8 \mathrm{H},-\mathrm{CH}_{2} \mathrm{Ph}\right), 3.88(\mathrm{~m}, 8 \mathrm{H},-\mathrm{CHMe}$ ), 2.47 (br s, $32 \mathrm{H}$, $\left.-\mathrm{OOCCH}_{2} \mathrm{C}_{6} \mathrm{H}_{4} \mathrm{NMe}_{2}-\mathrm{O}\right), 1.28\left(\mathrm{t}, \mathrm{J}=8 \mathrm{~Hz}, 48 \mathrm{H},-\mathrm{CHMe}_{2}\right),{ }^{13} \mathrm{C}$ NMR (100 MHz, $\left.\mathrm{C}_{6} \mathrm{D}_{6}, 25^{\circ} \mathrm{C}\right): \delta=186.2(\mathrm{~s}, \mathrm{OCO}), 165.1(\mathrm{~s}, \mathrm{NCN})$, 152.7 (s, Ar), 143.9 (s, Ar), 142.5 (s, Ar), 136.6 (s, Ar), 131.1 (s, Ar), 130.6 (s, Ar), 129.0 (s, Ar), 127.0 (s, Ar), 126.6 (s, Ar), 123.6 (s, Ar), 123.4 (s, Ar), 123.3 (s, Ar), 123.1 (s, Ar), 122.9 (s, Ar), 119.3 (s, Ar), $52.2\left(\mathrm{~s},-\mathrm{CH}_{2} \mathrm{Ph}\right.$ ), 45.1 (br s, $-\mathrm{OOCCH}_{2} \mathrm{C}_{6} \mathrm{H}_{4} \mathrm{NMe}_{2}-\mathrm{o}$ ), 27.9 (s, $\left.-\mathrm{CHMe}_{2}\right), 25.6(\mathrm{~s},-\mathrm{CHMe}$ ), 23.9 (s, -CHMe $)$. Calcd for $\mathrm{C}_{118} \mathrm{H}_{144} \mathrm{~N}_{10} \mathrm{O}_{8} \mathrm{Y}_{2}$ (\%): C, 70.57; H, 7.23; N, 6.97; found: C, 70.52; $\mathrm{H}, 7.33 ; \mathrm{N}, 6.74$.

\subsection{Synthesis of $\left\{\left[\left(\mathrm{PhCH}_{2}\right)_{2} \mathrm{NC}\left(\mathrm{NC}_{6} \mathrm{H}_{4}{ }^{i} \mathrm{Pr}_{2}-2,6\right)_{2}\right] \mathrm{La}\left(\mu-\eta^{2}: \eta^{1}\right.\right.$ - $\left.\left.\mathrm{O}_{2} \mathrm{CCH}_{2} \mathrm{C}_{6} \mathrm{H}_{4} \mathrm{NMe}_{2}-\sigma\right)\left(\mu-\eta^{1}: \eta^{1}-\mathrm{O}_{2} \mathrm{CCH}_{2} \mathrm{C}_{6} \mathrm{H}_{4} \mathrm{NMe}_{2}-o\right)\right\}_{2}(3 \mathrm{~b})$}

Complex 3b was obtained as a colourless crystalline product $(0.38 \mathrm{~g}, 73 \%)$, similarly to the preparation of 3a described above. ${ }^{1} \mathrm{H}$ NMR $\left(400 \mathrm{MHz}, \mathrm{C}_{6} \mathrm{D}_{6}, 25{ }^{\circ} \mathrm{C}\right): \delta=7.35-7.29(\mathrm{~m}, 4 \mathrm{H}, \mathrm{Ar}), 7.22-$ 7.18 (m, 5H, Ar), 7.04-7.00 (m, 12H, Ar), 6.91-6.88 (m, 10H, Ar), 6.86-6.82 (m, 4H, Ar), $6.68(\mathrm{~d}, J=4 \mathrm{~Hz}, 8 \mathrm{H}, \mathrm{Ar}), 4.08(\mathrm{~s}, 8 \mathrm{H}$, $\left.-\mathrm{CH}_{2} \mathrm{Ph}\right), 3.80\left(\mathrm{~m}, 8 \mathrm{H},-\mathrm{CHMe}_{2}\right), 3.47$ (br s, $8 \mathrm{H},-\mathrm{OOCCH}_{2} \mathrm{C}_{6}$ $\mathrm{H}_{4} \mathrm{NMe}_{2}-\mathrm{o}$ ), 2.54 (s, 24H, $-\mathrm{OOCCH}_{2} \mathrm{C}_{6} \mathrm{H}_{4} \mathrm{NMe} e_{2}-\mathrm{o}$ ), 1.29 (d, $J=$ $\left.4 \mathrm{~Hz}, 24 \mathrm{H},-\mathrm{CHMe} e_{2}\right), 1.25$ (d, $\left.J=4 \mathrm{~Hz}, 24 \mathrm{H},-\mathrm{CHM} e_{2}\right),{ }^{13} \mathrm{C} \mathrm{NMR}$ $\left(100 \mathrm{MHz}, \mathrm{C}_{6} \mathrm{D}_{6}, 25^{\circ} \mathrm{C}\right): \delta=183.6(\mathrm{~s}, \mathrm{OCO}), 163.4(\mathrm{~s}, \mathrm{NCN}), 153.3$ (s, Ar), 143.8 (s, Ar), 142.3 (s, Ar), 131.5 (s, Ar), 129.3 (s, Ar), 128.8 (s, Ar), 127.5 (s, Ar), 127.0 (s, Ar), 123.6 (s, Ar), 123.6 (s, Ar), 123.4 (s, Ar), 119.8 (s, Ar), 52.0 (s, $\left.-\mathrm{CH}_{2} \mathrm{Ph}\right), 45.6$ (s, $-\mathrm{OOCCH}_{2} \mathrm{C}_{6} \mathrm{H}_{4}-$ $\mathrm{NMe}_{2}-\mathrm{o}$ ), 38.6 (s, $\left.-\mathrm{OOCCH}_{2} \mathrm{C}_{6} \mathrm{H}_{4} \mathrm{NMe}_{2}-\mathrm{o}\right), 28.4\left(\mathrm{~s},-C \mathrm{HMe}_{2}\right), 26.6$ $\left(\mathrm{s},-\mathrm{CHMe} e_{2}\right.$ ), 23.7 (s, $-\mathrm{CHMe} e_{2}$ ). Calcd for $\mathrm{C}_{118} \mathrm{H}_{144} \mathrm{~N}_{10} \mathrm{O}_{8} \mathrm{La}_{2}(\%)$ : C, 67.22; H, 6.88; N, 6.64; found: C, 66.70; H, 7.45; N, 5.97.

\subsection{Synthesis of $\left\{\left[\left(\mathrm{PhCH}_{2}\right)_{2} \mathrm{NC}\left(\mathrm{NC}_{6} \mathrm{H}_{4}{ }^{i} \mathrm{Pr}_{2}-2,6\right)_{2}\right] \mathrm{Dy}\left(\mu-\eta^{2}: \eta^{1}-\right.\right.$ $\left.\left.\mathrm{O}_{2} \mathrm{CCH}_{2} \mathrm{C}_{6} \mathrm{H}_{4} \mathrm{NMe}_{2}-o\right)\left(\mu-\eta^{1}: \eta^{1}-\mathrm{O}_{2} \mathrm{CCH}_{2} \mathrm{C}_{6} \mathrm{H}_{4} \mathrm{NMe}_{2}-o\right)\right\}_{2}(3 \mathrm{c})$}

Complex 3c was obtained as a colourless crystalline product $(0.47 \mathrm{~g}, 88 \%)$, similarly to the preparation of 3a described above.
Calcd for $\mathrm{C}_{118} \mathrm{H}_{144} \mathrm{~N}_{10} \mathrm{O}_{8} \mathrm{Dy}_{2}$ (\%): C, 65.75; H, 6.73; N, 6.50; found: C, 66.16; H, 6.92; N, 6.56.

\subsection{Synthesis of $\left\{\left[\left(\mathrm{PhCH}_{2}\right)_{2} \mathrm{NC}\left(\mathrm{NC}_{6} \mathrm{H}_{4}{ }^{i} \mathrm{Pr}_{2}-2,6\right)_{2}\right] \mathrm{Lu}\left(\mu-\eta^{2}: \eta^{1}-\right.\right.$ $\left.\left.\mathrm{O}_{2} \mathrm{CCH}_{2} \mathrm{C}_{6} \mathrm{H}_{4} \mathrm{NMe}_{2}-\sigma\right)\left(\mu-\eta^{1}: \eta^{1}-\mathrm{O}_{2} \mathrm{CCH}_{2} \mathrm{C}_{6} \mathrm{H}_{4} \mathrm{NMe}_{2}-o\right)\right\}_{2}$ (3d)}

Complex 3d was obtained as a colourless crystalline product $(0.50 \mathrm{~g}, 92 \%)$, similarly to the preparation of 3a described above. ${ }^{1} \mathrm{H}$ NMR (400 MHz, $\left.\mathrm{C}_{6} \mathrm{D}_{6}, 25{ }^{\circ} \mathrm{C}\right): \delta=7.36-7.29(\mathrm{~m}, 10 \mathrm{H}, \mathrm{Ar})$, 7.01-6.87 (m, 30H, Ar), 6.70 (d, $J=4 \mathrm{~Hz}, 8 \mathrm{H}, \mathrm{Ar}), 4.14$ (s, 8H, $\left.-\mathrm{CH}_{2} \mathrm{Ph}\right), 3.91\left(\mathrm{~m}, 8 \mathrm{H},-\mathrm{CH} \mathrm{Me}_{2}\right), 3.50\left(\mathrm{br} \mathrm{s}, 8 \mathrm{H},-\mathrm{OOCCH}_{2} \mathrm{C}_{6}\right.$ $\mathrm{H}_{4} \mathrm{NMe}_{2}-\mathrm{o}$ ), 2.62-2.40 (m, 24H, $\left.-\mathrm{OOCCH}_{2} \mathrm{C}_{6} \mathrm{H}_{4} \mathrm{NMe}_{2}-\mathrm{o}\right)$, 1.311.27 (m, 48H, $\left.-\mathrm{CHMe}_{2}\right),{ }^{13} \mathrm{C} \mathrm{NMR}\left(100 \mathrm{MHz}, \mathrm{C}_{6} \mathrm{D}_{6}, 25{ }^{\circ} \mathrm{C}\right): \delta=$ 183.7 (s, OCO), 164.7 (s, NCN), 153.0 (s, Ar), 144.2 (s, Ar), 143.2 (s, Ar), 136.9 (s, Ar), 131.4 (br s, Ar), 127.3 (br s, Ar), 127.0 (s, Ar), 124.0 (s, Ar), 123.8 (s, Ar), 123.7 (s, Ar), 119.4 (br s, Ar), 52.6 (s, $\left.-\mathrm{CH}_{2} \mathrm{Ph}\right), \quad 45.4 \quad\left(\mathrm{~s}, \quad-\mathrm{OOCCH}_{2} \mathrm{C}_{6} \mathrm{H}_{4} \mathrm{NMe}_{2}-\mathrm{O}\right.$ ), 38.0 (br s, $-\mathrm{OOCCH}_{2} \mathrm{C}_{6} \mathrm{H}_{4} \mathrm{NMe}_{2}-\mathrm{O}$ ), 28.3 (s, $-\mathrm{CHMe}_{2}$ ), 26.0 (s, $-\mathrm{CHMe}_{2}$ ), 24.4 (s, $-\mathrm{CHMe}_{2}$ ). Calcd for $\mathrm{C}_{118} \mathrm{H}_{144} \mathrm{~N}_{10} \mathrm{O}_{8} \mathrm{Lu}_{2}$ (\%): C, 65.00; $\mathrm{H}$, 6.66 ; N, 6.50; found: C, 65.68; H, 6.39; N, 6.05.

\subsection{Synthesis of $\left\{\left[\left(\mathrm{PhCH}_{2}\right)_{2} \mathrm{NC}\left(\mathrm{NC}_{6} \mathrm{H}_{4}{ }^{i} \mathrm{Pr}_{2}-2,6\right)_{2}\right] \mathrm{Y}\right.$ $\left.\left[\mu-\mathrm{S}\left(\mathrm{CH}_{2} \mathrm{C}_{6} \mathrm{H}_{4} \mathrm{NMe}_{2}-o\right)\right]_{2}\right\}_{2}(4 a)$}

To a stirred THF $(20 \mathrm{~mL})$ solution of complex $2 \mathrm{a}(0.46 \mathrm{~g}, 0.5$ $\mathrm{mmol})$ was added slowly a THF $(10 \mathrm{~mL})$ solution of $\mathrm{S}_{8}(0.032 \mathrm{~g}$, $0.125 \mathrm{mmol})$. The reaction solution was left to stir for 3.5 days at $65{ }^{\circ} \mathrm{C}$, and all volatiles were removed under vacuum. After being washed with cold hexane, the oily residue turned to white powder which then was collected by filtration. The white powder was recrystallized in toluene at room temperature for 2 days to give a colourless crystalline complex 4 a $0.38 \mathrm{~g}(77 \%) .{ }^{1} \mathrm{H}$ NMR (400 MHz, $\left.\mathrm{C}_{6} \mathrm{D}_{6}, 25{ }^{\circ} \mathrm{C}\right): \delta=7.76-7.73$ (m, 3H, Ar), 7.157.15 (m, 11H, Ar), 7.01-6.95 (m, 12H, Ar), 6.88-6.81 (m, 15H, Ar), 6.51-6.49 (m, 7H, Ar), 4.28 (br s, 8H, $-\mathrm{SCH}_{2} \mathrm{C}_{6} \mathrm{H}_{4} \mathrm{NMe}_{2}-0$ ), 4.12 (s, $\left.8 \mathrm{H},-\mathrm{CH}_{2} \mathrm{Ph}\right), 3.89\left(\mathrm{~m}, 8 \mathrm{H},-\mathrm{CHMe} \mathrm{M}_{2}\right), 2.58$ (s, 24H, $-\mathrm{NMe} e_{2}$ ), 1.43 (br s, 24H, $-\mathrm{CHMe}$ ), 1.27 (d, J = 4.0 Hz, 24H, $-\mathrm{CHMe} e_{2}$ ), ${ }^{13} \mathrm{C}$ NMR (100 MHz, $\left.\mathrm{C}_{6} \mathrm{D}_{6}, 25{ }^{\circ} \mathrm{C}\right): \delta=166.09$ (s, NCN), 152.6 (s, Ar), 143.3 (s, Ar), 142.7 (s, Ar), 137.8 (s, Ar), 135.9 (s, Ar), 131.3 (s, Ar), 129.4 (s, Ar), 127.2 (s, Ar), 126.5 (s, Ar), 124.6 (s, Ar), 124.2 (s, Ar), 123.0 (s, Ar), 118.3 (s, Ar), 52.5 (s, $\left.-\mathrm{CH}_{2} \mathrm{Ph}\right), 45.2$ (s, $-\mathrm{NMe}_{2}$ ), 34.6 (s, $-\mathrm{SCH}_{2} \mathrm{C}_{6} \mathrm{H}_{4} \mathrm{NMe}_{2}-\mathrm{o}$ ), 29.0 (s, $-\mathrm{CHMe}_{2}$ ), 26.2 (s, - $\mathrm{CHMe}$ ), 24.2 (s, $-\mathrm{CHMe} 2$ ). Calcd for $\mathrm{C}_{114} \mathrm{H}_{144} \mathrm{~N}_{10} \mathrm{~S}_{4} \mathrm{Y}_{2}$ (\%): C, 69.84; H, 7.40; N, 7.14; found: C, 69.40; H, 7.44; N, 6.73.

\subsection{Synthesis of $\left\{\left[\left(\mathrm{PhCH}_{2}\right)_{2} \mathrm{NC}\left(\mathrm{NC}_{6} \mathrm{H}_{4}{ }^{i} \mathrm{Pr}_{2}-2,6\right)_{2}\right] \mathrm{La}\right.$ $\left.\left[\mu-\mathrm{S}\left(\mathrm{CH}_{2} \mathrm{C}_{6} \mathrm{H}_{4} \mathrm{NMe}_{2}-o\right)\right]_{2}\right\}_{2}(4 \mathrm{~b})$}

To a stirred THF $(20 \mathrm{~mL})$ solution of complex $2 \mathbf{b}(0.48 \mathrm{~g}, 0.5$ $\mathrm{mmol})$ was added slowly a THF $(10 \mathrm{~mL})$ solution of $\mathrm{S}_{8}(0.032 \mathrm{~g}$, $0.125 \mathrm{mmol}$ ). After it was stirred at room temperature for $12 \mathrm{~h}$, all volatiles were removed under vacuum, and washed with cold hexane, the oily residue turn to white powder which then was collected by filtration. The white powder was recrystallized in toluene at $-35{ }^{\circ} \mathrm{C}$ for 3 days to give a colourless crystalline complex 4b $0.31 \mathrm{~g}(61 \%) .{ }^{1} \mathrm{H}$ NMR $\left(400 \mathrm{MHz}, \mathrm{C}_{6} \mathrm{D}_{6}, 25{ }^{\circ} \mathrm{C}\right): \delta=$ $7.62(\mathrm{~d}, J=4.0 \mathrm{~Hz}, 3 \mathrm{H}, \mathrm{Ar}), 7.17-7.14$ (m, 7H, Ar), 7.10-7.05 (m, 12H, Ar), 6.98-6.92 (m, 8H, Ar), 6.89-6.86 (m, 11H, Ar), 6.616.60 (m, 7H, Ar), 4.52 (br s, $8 \mathrm{H},-\mathrm{SCH}_{2} \mathrm{C}_{6} \mathrm{H}_{4} \mathrm{NMe}_{2}-0$ ), 4.04 (s, 8H, 
$-\mathrm{CH}_{2} \mathrm{Ph}$ ), 3.77 (m, 8H, $-\mathrm{CHMe}$ ), 2.61 (s, 24H, $\left.-\mathrm{NMe} e_{2}\right), 1.48$ (d, $\left.=4.0 \mathrm{~Hz}, 24 \mathrm{H},-\mathrm{CHMe} e_{2}\right), 1.22\left(\mathrm{~d}, J=4.0 \mathrm{~Hz}, 24 \mathrm{H},-\mathrm{CHMe} e_{2}\right),{ }^{13} \mathrm{C}$ NMR (100 MHz, $\left.\mathrm{C}_{6} \mathrm{D}_{6}, 25{ }^{\circ} \mathrm{C}\right): \delta=164.4(\mathrm{~s}, \mathrm{NCN}), 152.5(\mathrm{~s}, \mathrm{Ar})$, 142.7 (s, Ar), 142.6 (s, Ar), 138.7 (s, Ar), 136.4 (s, Ar), 131.2 (s, Ar), 129.2 (s, Ar), 128.8 (s, Ar), 127.1 (s, Ar), 126.4 (s, Ar), 124.2 (s, Ar), 124.1 (s, Ar), 123.3 (s, Ar), 118.7 (s, Ar), 51.8 (s, $\left.-C_{2} \mathrm{Ph}\right), 45.3$ (s, $-\mathrm{NMe}_{2}$ ), 33.5 (s, $-\mathrm{SCH}_{2} \mathrm{C}_{6} \mathrm{H}_{4} \mathrm{NMe}_{2}-\mathrm{o}$ ), 28.8 (s, $-\mathrm{CHMe}_{2}$ ), 27.6 (s, $-\mathrm{CHMe}_{2}$ ), 23.6 (s, $-\mathrm{CHMe}$ ). Calcd for $\mathrm{C}_{114} \mathrm{H}_{144} \mathrm{~N}_{10} \mathrm{~S}_{4} \mathrm{La}_{2}$ (\%): C, 66.45; H, 7.04; N, 6.80; found: C, 66.07; H, 6.91; N, 6.60.

\subsection{Synthesis of $\left\{\left[\left(\mathrm{PhCH}_{2}\right)_{2} \mathrm{NC}\left(\mathrm{NC}_{6} \mathrm{H}_{4}{ }^{i} \mathrm{Pr}_{2}-2,6\right)_{2}\right] \mathrm{Dy}\right.$ $\left.\left[\mu-\mathrm{S}\left(\mathrm{CH}_{2} \mathrm{C}_{6} \mathrm{H}_{4} \mathrm{NMe}_{2}-\mathrm{o}\right)\right]_{2}\right\}_{2}(4 \mathrm{c})$}

Complex 4c was obtained as a colourless crystalline product $(0.38 \mathrm{~g}, 73 \%)$, similarly to the preparation of 4 a described above. Calcd for $\mathrm{C}_{114} \mathrm{H}_{144} \mathrm{~N}_{10} \mathrm{~S}_{4} \mathrm{Dy}_{2}$ (\%): C, 64.96; H, 6.89; N, 6.65; found: $\mathrm{C}, 64.84 ; \mathrm{H}, 6.83 ; \mathrm{N}, 6.73$.

\subsection{Synthesis of $\left\{\left[\left(\mathrm{PhCH}_{2}\right)_{2} \mathrm{NC}\left(\mathrm{NC}_{6} \mathrm{H}_{4}{ }^{i} \mathrm{Pr}_{2}-2,6\right)_{2}\right] \mathrm{Lu}\right.$ $\left.\left[\mu-\mathrm{S}\left(\mathrm{CH}_{2} \mathrm{C}_{6} \mathrm{H}_{4} \mathrm{NMe}_{2}-\boldsymbol{o}\right)\right]_{2}\right\}_{2}(\mathbf{4 d})$}

Complex 4d was obtained as a colourless crystalline product $(0.36 \mathrm{~g}, 67 \%)$, similarly to the preparation of $4 \mathbf{a}$ described above. ${ }^{1} \mathrm{H}$ NMR $\left(400 \mathrm{MHz}, \mathrm{C}_{6} \mathrm{D}_{6}, 25^{\circ} \mathrm{C}\right): \delta=7.83-7.80(\mathrm{~m}, 3 \mathrm{H}, \mathrm{Ar}), 7.18-$ $7.16(\mathrm{~m}, 14 \mathrm{H}, \mathrm{Ar}), 6.87-6.81(\mathrm{~m}, 12 \mathrm{H}, \mathrm{Ar}), 6.48(\mathrm{~d}, J=4.0 \mathrm{~Hz}, 6 \mathrm{H}$, $\mathrm{Ar}$ ), 4.46 (br s, $8 \mathrm{H},-\mathrm{SCH}_{2} \mathrm{C}_{6} \mathrm{H}_{4} \mathrm{NMe}_{2}-\mathrm{o}$ ), 4.13 (s, 8H, $-\mathrm{CH}_{2} \mathrm{Ph}$ ), $3.95\left(\mathrm{~m}, 8 \mathrm{H},-\mathrm{CHMe}\right.$ ), 2.57 (s, 24H, $\left.-\mathrm{NMe} e_{2}\right), 1.41(\mathrm{~d}, J=8.0 \mathrm{~Hz}$, $\left.24 \mathrm{H},-\mathrm{CHMe} e_{2}\right), 1.30$ (d, $\left.J=4.0 \mathrm{~Hz}, 24 \mathrm{H},-\mathrm{CHMe} e_{2}\right),{ }^{13} \mathrm{C}$ NMR $(100$ $\left.\mathrm{MHz}, \mathrm{C}_{6} \mathrm{D}_{6}, 25^{\circ} \mathrm{C}\right): \delta=165.3(\mathrm{~s}, \mathrm{NCN}), 152.3(\mathrm{~s}, \mathrm{Ar}), 142.8(\mathrm{~s}, \mathrm{Ar})$, 142.6 (s, Ar), 137.3 (s, Ar), 135.4 (s, Ar), 130.8 (s, Ar), 129.0 (s, Ar), 126.7 (s, Ar), 126.1 (s, Ar), 124.4 (s, Ar), 123.7 (s, Ar), 122.5 (s, Ar), 117.9 (s, Ar), 52.4 (s, $\left.-\mathrm{CH}_{2} \mathrm{Ph}\right), 44.7$ (s, $-\mathrm{NMe} \mathrm{e}_{2}$ ), $34.3\left(\mathrm{~s},-\mathrm{SCH}_{2}-\right.$ $\mathrm{C}_{6} \mathrm{H}_{4} \mathrm{NMe}_{2}-\mathrm{o}$ ), $28.6\left(\mathrm{~s},-\mathrm{CHMe}_{2}\right), 25.6\left(\mathrm{~s},-\mathrm{CHMe} e_{2}\right), 23.8(\mathrm{~s}$, ${ }_{-} \mathrm{CHMe}_{2}$ ). Calcd for $\mathrm{C}_{114} \mathrm{H}_{144} \mathrm{~N}_{10} \mathrm{~S}_{4} \mathrm{Lu}_{2}$ (\%): C, 64.20; H, 6.81; N, 6.57; found: C, 64.58; H, 7.51; N, 6.18.

\subsection{Synthesis of $\left[\left(\mathrm{PhCH}_{2}\right)_{2} \mathrm{NC}\left(\mathrm{NC}_{6} \mathrm{H}_{4}{ }^{i} \mathrm{Pr}_{2}-2,6\right)_{2}\right] \mathrm{Y}$ $\left\{\mathrm{SC}\left(\mathrm{CH}_{2} \mathrm{C}_{6} \mathrm{H}_{4} \mathrm{NMe}_{2}-\mathrm{o}\right) \mathrm{NPh}\right\}_{2}(5 \mathrm{a})$}

A THF $(10 \mathrm{~mL})$ solution of PhNCS $(0.108 \mathrm{~mL}, 1 \mathrm{mmol})$ was added slowly to a stirred THF $(20 \mathrm{~mL})$ solution of complex $2 \mathbf{a}$ $(0.46 \mathrm{~g}, 0.5 \mathrm{mmol})$. The reaction solution was left to stir at room temperature for $12 \mathrm{~h}$ and all volatiles were removed under vacuum. After being washed with cold hexane, the oily residue turned to white powder which then was collected by filtration and dissolved in toluene. The solution was concentrated to saturation and stood at ambient temperature. Colourless crystals of 5a (0.46 g, 77\%) were obtained after 2 days. ${ }^{1} \mathrm{H}$ NMR (400 $\left.\mathrm{MHz}, \mathrm{C}_{6} \mathrm{D}_{6}, 25^{\circ} \mathrm{C}\right): \delta=7.74-7.71(\mathrm{~m}, 2 \mathrm{H}, \mathrm{Ar}), 7.19-7.14(\mathrm{~m}, 4 \mathrm{H}$, $\mathrm{Ar}$ ), 7.04 (br s, 6H, Ar), 6.95-6.92 (m, 2H, Ar), 6.95-6.92 (m, 2H, Ar), 6.89-6.83 (m, 10H, Ar), 6.80-6.76 (m, 2H, Ar), 6.66-6.65 (m, $4 \mathrm{H}, \mathrm{Ar}), 6.39$ (d, J = 8.0 Hz, $4 \mathrm{H}, \mathrm{Ar}), 4.20\left(\mathrm{~s}, 4 \mathrm{H},-\mathrm{CH}_{2} \mathrm{Ph}\right), 4.14(\mathrm{~s}$, $\left.4 \mathrm{H},-\mathrm{CH}_{2} \mathrm{C}_{6} \mathrm{H}_{4} \mathrm{NMe}_{2}-\mathrm{O}\right), 3.94\left(\mathrm{~m}, 4 \mathrm{H},-\mathrm{CHMe}_{2}\right), 2.37(\mathrm{~s}, 12 \mathrm{H}$, $-\mathrm{NMe}_{2}$ ), 1.27 (d, $\left.J=8.0 \mathrm{~Hz}, 12 \mathrm{H},-\mathrm{CHMe}_{2}\right), 1.23$ (d, $J=4.0 \mathrm{~Hz}$, $\left.12 \mathrm{H},-\mathrm{CHMe} e_{2}\right),{ }^{13} \mathrm{C} \mathrm{NMR}\left(100 \mathrm{MHz}, \mathrm{C}_{6} \mathrm{D}_{6}, 25{ }^{\circ} \mathrm{C}\right): \delta=199.8(\mathrm{~s}$, $\mathrm{NCS}$ ), 165.2 (s, NCN), 153.4 (s, Ar), 147.7 (s, Ar), 143.6 (s, Ar), 143.1 (s, Ar), 136.1 (s, Ar), 133.0 (s, Ar), 131.0 (s, Ar), 129.5 (s, Ar), 129.0 (s, Ar), 127.2 (s, Ar), 124.6 (s, Ar), 124.4 (s, Ar), 124.1 (s, Ar), 123.8 (s, Ar), 123.3 (s, Ar), 120.2 (s, Ar), 52.4 (s, $\left.-\mathrm{CH}_{2} \mathrm{Ph}\right), 44.9$ (s,
$-\mathrm{NMe}_{2}$ ), $42.4\left(\mathrm{~s},-\mathrm{CH}_{2} \mathrm{C}_{6} \mathrm{H}_{4} \mathrm{NMe}_{2}-\mathrm{o}\right.$ ), 28.7 (s, $-\mathrm{CHMe}_{2}$ ), 25.7 (s, $-\mathrm{CHMe}_{2}$ ), 24.2 (s, $-\mathrm{CHMe}_{2}$ ). Calcd for $\mathrm{C}_{71} \mathrm{H}_{82} \mathrm{~N}_{7} \mathrm{~S}_{2} \mathrm{Y}$ (\%): C, 71.87; $\mathrm{H}, 6.97$; N, 8.26; found: C, 70.97; H, 7.34; N, 8.08.

\subsection{Synthesis of $\left[\left(\mathrm{PhCH}_{2}\right)_{2} \mathrm{NC}\left(\mathrm{NC}_{6} \mathrm{H}_{4}{ }^{i} \mathrm{Pr}_{2}-2,6\right)_{2}\right] \mathrm{La}$ $\left\{\mathrm{SC}\left(\mathrm{CH}_{2} \mathrm{C}_{6} \mathrm{H}_{4} \mathrm{NMe}_{2}-\mathrm{o}\right) \mathrm{NPh}\right\}_{2}$ (THF) (5b)}

A THF $(10 \mathrm{~mL})$ solution of PhNCS $(0.108 \mathrm{~mL}, 1 \mathrm{mmol})$ was added slowly to a stirred THF $(20 \mathrm{~mL})$ solution of complex $2 \mathbf{b}$ $(0.48 \mathrm{~g}, 0.5 \mathrm{mmol})$. The reaction solution was left to stir at room temperature for $12 \mathrm{~h}$ and all volatiles were removed under vacuum. After being washed with cold hexane, the oily residue turned to white powder which then was collected by filtration and dissolved in toluene. The solution was concentrated to saturation and layered with $2 \mathrm{~mL}$ hexane solvent. White participate $\mathbf{5 b}$ was obtained after the solution stood at $-35{ }^{\circ} \mathrm{C}$ for 3 days. Yield $(0.28 \mathrm{~g}, 46 \%) .{ }^{1} \mathrm{H} \mathrm{NMR}\left(400 \mathrm{MHz}, \mathrm{C}_{6} \mathrm{D}_{6}, 25{ }^{\circ} \mathrm{C}\right)$ : $\delta=7.72-7.70(\mathrm{~m}, 2 \mathrm{H}, \mathrm{Ar}), 7.13-7.08(\mathrm{~m}, 8 \mathrm{H}, \mathrm{Ar}), 7.03-6.82(\mathrm{~m}$, $22 \mathrm{H}, \mathrm{Ar}$ ), 6.37 (d, J=8 Hz, $4 \mathrm{H}, \mathrm{Ar}), 4.17$ (s, 4H, $-\mathrm{CH}_{2} \mathrm{C}_{6} \mathrm{H}_{4} \mathrm{NMe}_{2}-$ o), $4.12\left(\mathrm{~s}, 4 \mathrm{H},-\mathrm{CH}_{2} \mathrm{Ph}\right), 3.98\left(\mathrm{~m}, 4 \mathrm{H},-\mathrm{CHMe} \mathrm{M}_{2}\right), 3.54(\mathrm{~m}, 4 \mathrm{H}$, THF), 2.36 (s, 12H, -NMe $\left.e_{2}\right), 1.36$ (d, J=8 Hz, 12H, $-\mathrm{CHMe}_{2}$ ), 1.22 (d \& $\left.\mathrm{m}, J=8 \mathrm{~Hz}, 24 \mathrm{H},-\mathrm{CHMe} e_{2} \& \mathrm{THF} \& \mathrm{Hex}\right),{ }^{13} \mathrm{C}$ NMR (100 $\left.\mathrm{MHz}, \mathrm{C}_{6} \mathrm{D}_{6}, 25{ }^{\circ} \mathrm{C}\right): \delta=198.9(\mathrm{~s}, \mathrm{NCS}), 163.1(\mathrm{~s}, \mathrm{NCN}), 153.2(\mathrm{~s}$, Ar), 148.9 (s, Ar), 142.6 (s, Ar), 137.2 (s, Ar), 131.3 (s, Ar), 129.5 (s, Ar), 128.9 (s, Ar), 128.8 (s, Ar), 128.3 (s, Ar), 127.5 (s, Ar), 127.2 (s, $\mathrm{Ar}), 124.4$ (s, Ar), 123.5 (s, Ar), 123.2 (s, Ar), 119.8 (s, Ar), 69.1 (s, THF), 51.7 (s, $\left.-\mathrm{CH}_{2} \mathrm{Ph}\right), 45.0\left(\mathrm{~s},-\mathrm{NMe} e_{2}\right), 43.2\left(\mathrm{~s},-\mathrm{CH}_{2} \mathrm{C}_{6} \mathrm{H}_{4} \mathrm{NMe}_{2}-\right.$ o), 28.5 (s, $-\mathrm{CHMe}_{2}$ ), 27.0 (s, -CHMe $\mathrm{C}_{2}$ ), 25.3 (s, THF), 24.1 (s, $-\mathrm{CHMe} e_{2}$ ). Calcd for $\mathrm{C}_{75} \mathrm{H}_{90} \mathrm{~N}_{7} \mathrm{~S}_{2} \mathrm{OLa}(\%): \mathrm{C}, 68.84 ; \mathrm{H}, 6.93 ; \mathrm{N}$, 7.49; found: C, 68.70; H, 7.06; N, 7.73.

\subsection{Synthesis of $\left[\left(\mathrm{PhCH}_{2}\right)_{2} \mathrm{NC}\left(\mathrm{NC}_{6} \mathrm{H}_{4}{ }^{i} \mathrm{Pr}_{2}-2,6\right)_{2}\right] \mathrm{Dy}$ $\left\{\mathrm{SC}\left(\mathrm{CH}_{2} \mathrm{C}_{6} \mathrm{H}_{4} \mathrm{NMe}_{2}-o\right) \mathrm{NPh}_{2}(5 \mathrm{c})\right.$}

Complex 5c was obtained as a colourless crystalline product $(0.44 \mathrm{~g}, 70 \%)$, similarly to the preparation of $5 \mathrm{a}$ described above. Calcd for $\mathrm{C}_{71} \mathrm{H}_{82} \mathrm{~N}_{7} \mathrm{~S}_{2} \mathrm{Dy}(\%)$ : C, 67.67; H, 6.56; N, 7.78; found $\mathrm{C}$, 67.59; H, 6.87; N, 7.80.

\subsection{Synthesis of $\left[\left(\mathrm{PhCH}_{2}\right)_{2} \mathrm{NC}\left(\mathrm{NC}_{6} \mathrm{H}_{4}{ }^{i} \mathrm{Pr}_{2}-2,6\right)_{2}\right] \mathrm{Lu}$ $\left\{\mathrm{SC}\left(\mathrm{CH}_{2} \mathrm{C}_{6} \mathrm{H}_{4} \mathrm{NMe}_{2}-\mathrm{o}\right) \mathrm{NPh}\right\}_{2}(5 \mathrm{~d})$}

Complex 5d was obtained as a colourless crystalline product $(0.41 \mathrm{~g}, 65 \%)$, similarly to the preparation of $5 \mathrm{a}$ described above. ${ }^{1} \mathrm{H}$ NMR $\left(400 \mathrm{MHz}, \mathrm{C}_{6} \mathrm{D}_{6}, 25^{\circ} \mathrm{C}\right): \delta=7.79-7.76(\mathrm{~m}, 2 \mathrm{H}, \mathrm{Ar}), 7.20-$ 7.14 (m, 5H, Ar), 7.05 (br s, 6H, Ar), 6.95-6.84 (m, 9H, Ar), 6.78$6.75(\mathrm{~m}, 2 \mathrm{H}, \mathrm{Ar}), 6.65$ (br s, 4H, Ar), 6.38 (d, J=8.0 Hz, 4H, Ar), 4.25 (br s, $\left.4 \mathrm{H},-\mathrm{CH}_{2} \mathrm{Ph}\right), 4.15\left(\mathrm{~s}, 4 \mathrm{H},-\mathrm{CH}_{2} \mathrm{C}_{6} \mathrm{H}_{4} \mathrm{NMe}_{2}-\mathrm{O}\right), 4.02(\mathrm{~m}$, $4 \mathrm{H},-\mathrm{C} H \mathrm{Me}_{2}$ ), $2.36\left(\mathrm{~s}, 12 \mathrm{H},-\mathrm{NMe} e_{2}\right), 1.29$ (d, $J=8.0 \mathrm{~Hz}, 12 \mathrm{H}$, $-\mathrm{CHMe} e_{2}$ ), 1.23 (br s, 12H, $-\mathrm{CHMe} e_{2}$ ), ${ }^{13} \mathrm{C} \mathrm{NMR}\left(100 \mathrm{MHz}, \mathrm{C}_{6} \mathrm{D}_{6}\right.$, $\left.25{ }^{\circ} \mathrm{C}\right): \delta=200.2(\mathrm{~s}, \mathrm{NCS}), 165.1(\mathrm{~s}, \mathrm{NCN}), 153.4(\mathrm{~s}, \mathrm{Ar}), 147.4(\mathrm{~s}$, Ar), 143.6 (s, Ar), 143.5 (s, Ar), 136.0 (s, Ar), 133.0 (s, Ar), 130.9 (s, Ar), 129.6 (s, Ar), 128.9 (s, Ar), 127.2 (s, Ar), 124.8 (s, Ar), 124.4 (s, $\mathrm{Ar}), 124.3$ (s, Ar), 123.8 (s, Ar), 123.4 (s, Ar), 120.2 (s, Ar), 52.6 (s, $-\mathrm{CH}_{2} \mathrm{Ph}$ ), $45.0\left(\mathrm{~s},-\mathrm{NMe} \mathrm{e}_{2}\right), 42.6\left(\mathrm{~s},-\mathrm{CH}_{2} \mathrm{C}_{6} \mathrm{H}_{4} \mathrm{NMe}_{2}-\mathrm{o}\right), 28.6$ (s, $\left.-\mathrm{CHMe}_{2}\right), 25.7\left(\mathrm{~s},-\mathrm{CHMe} \mathrm{e}_{2}\right), 24.6$ (s, -CHMe $)$. Calcd for $\mathrm{C}_{71} \mathrm{H}_{82} \mathrm{~N}_{7} \mathrm{~S}_{2} \mathrm{Lu}(\%): \mathrm{C}, 67.01 ; \mathrm{H}, 6.49 ; \mathrm{N}, 7.70$; found: C, 66.80; H, $6.81 ; \mathrm{N}, 7.60$. 


\subsection{Typical procedure for polymerization of isoprene}

The procedures for isoprene polymerization were similar, thus take complex 2a as an example and corresponding polymerization procedure is given below. For $2 \mathrm{a} /\left[\mathrm{Ph}_{3} \mathrm{C}\right]\left[\mathrm{B}\left(\mathrm{C}_{6} \mathrm{~F}_{5}\right)_{4}\right]$ binary system: in a glovebox, a magnetic stir bar was placed in a 100 $\mathrm{mL}$ flask, to which a dropping funnel was attached. Isoprene (1.022 g, $15 \mathrm{mmol}), 2 \mathrm{a}(0.018 \mathrm{~g}, 0.020 \mathrm{mmol})$ and $\mathrm{C}_{6} \mathrm{H}_{5} \mathrm{Cl}(8 \mathrm{~mL})$ were charged into the flask. $\mathrm{A} \mathrm{C}_{6} \mathrm{H}_{5} \mathrm{Cl}$ solution $(2 \mathrm{~mL})$ of $\left[\mathrm{Ph}_{3} \mathrm{C}\right]$ $\left[\mathrm{B}\left(\mathrm{C}_{6} \mathrm{~F}_{5}\right)_{4}\right](0.0185 \mathrm{~g}, 0.020 \mathrm{mmol})$ was charged to the dropping funnel. The reaction apparatus was moved outside and placed in a water bath $\left(25^{\circ} \mathrm{C}\right)$. After $10 \mathrm{~min}$, the $\mathrm{C}_{6} \mathrm{H}_{5} \mathrm{Cl}$ solution of $\left[\mathrm{Ph}_{3} \mathrm{C}\right]\left[\mathrm{B}\left(\mathrm{C}_{6} \mathrm{~F}_{5}\right)_{4}\right]$ was dropped into the mixture of $\mathbf{2 a}$ and isoprene under rapid stirring. After the mixture was stirred at $25{ }^{\circ} \mathrm{C}$ for $10 \mathrm{~min}$, methanol was injected to terminate the polymerization. The reaction mixture was poured into a large quantity $(200 \mathrm{~mL})$ of methanol containing a small amount of hydrochloric acid and butylhydroxytoluene (BHT) as a stabilizing agent under stirring. The precipitated polymer was isolated by decantation, washed with methanol, and then dried under vacuum at $60{ }^{\circ} \mathrm{C}$ to a constant weight to afford $1.02 \mathrm{~g}$ of 3,4-rich polyisoprene ( $100 \%$ yield). For $2 \mathrm{a} /\left[\mathrm{Ph}_{3} \mathrm{C}\right]\left[\mathrm{B}\left(\mathrm{C}_{6} \mathrm{~F}_{5}\right)_{4}\right] /$ $\mathrm{AlR}_{3}$ ternary systems: isoprene (1.022 g, $\left.15 \mathrm{mmol}\right), 2 \mathrm{a}(0.018 \mathrm{~g}$, $0.020 \mathrm{mmol}), \mathrm{AlR}_{3}\left(100 \mu \mathrm{L}, 1 \mathrm{~mol} \mathrm{~L}^{-1}\right.$ in hexane $)$ and $\mathrm{C}_{6} \mathrm{H}_{5} \mathrm{Cl}(8$ $\mathrm{mL}$ ) were charged into the flask and other operations are same as above-mentioned binary system.

\section{Acknowledgements}

This work was supported by the NSFC, The National Basic Research Program (973 Program, No. 2012CB821604).

\section{Notes and references}

1 H. van der Heijden, C. J. Schaverien and A. G. Orpen, Organometallics, 1989, 8, 255.

2 (a) M. Nishiura and Z. Hou, Nat. Chem., 2010, 2, 257; (b) M. Nishiura, F. Guo and Z. Hou, Acc. Chem. Res., 2015, 48, 2209; (c) A. A. Trifonov and D. M. Lyubov, Coord. Chem. Rev., 2017, 340, 10.

3 W. E. Piers and D. J. H. Emslie, Coord. Chem. Rev., 2002, 233(234), 131.

4 (a) G. J. P. Britovsek, V. C. Gibson and D. F. Wass, Angew. Chem., Int. Ed., 1999, 38, 428; (b) F. T. Edelmann, D. M. M. Freckmann and H. Schumann, Chem. Rev., 2002, 102, 1851; (c) M. C. Baier, M. A. Zuideveld and S. Mecking, Angew. Chem., Int. Ed., 2014, 53, 9722.

5 (a) F. T. Edelmann, Chem. Soc. Rev., 2009, 38, 2253; (b) A. A. Trifonov, Coord. Chem. Rev., 2010, 254, 1327; (c) F. T. Edelmann, Chem. Soc. Rev., 2012, 41, 7657; (d) F. T. Edelmann, Adv. Organomet. Chem., 2013, 61, 55.

6 (a) A. A. Trifonov, D. M. Lyubov, G. K. Fukin, E. V. Baranov and Y. A. Kurskii, Organometallics, 2006, 25, 3935; (b) D. M. Lyubov, G. K. Fukin and A. A. Trifonov, Inorg. Chem.,
2007, 46, 11450; (c) S. Ge, A. Meetsma and B. Hessen, Organometallics, 2008, 27, 3131.

7 (a) M. Li, J. Hong, Z. Chen, X. Zhou and L. Zhang, Dalton Trans., 2013, 42, 8288; (b) J. Hong, L. Zhang, K. Wang, Z. Chen, L. Wu and X. Zhou, Organometallics, 2013, 32, 7312. 8 Y. J. Luo, X. L. Wang, J. Chen, C. C. Luo, Y. Zhang and Y. M. Yao, J. Organomet. Chem., 2009, 694, 1289.

9 (a) W. J. Evans, C. A. Seibel, J. W. Ziller and R. J. Doedens, Organometallics, 1998, 17, 2103; (b) W. J. Evans, J. C. Brady and J. W. Ziller, J. Am. Chem. Soc., 2001, 123, 7711; (c) D. Cui, M. Nishiura and Z. Hou, Macromolecules, 2005, 38, 4089; (d) W. J. Evans, J. M. Perotti and J. W. Ziller, J. Am. Chem. Soc., 2005, 127, 3894; (e) D. Cui, M. Nishiura, O. Tardif and Z. Hou, Organometallics, 2008, 27, 2428.

10 (a) Y. Li, C. Pi, J. Zhang, X. Zhou, Z. Chen and L. Weng, Organometallics, 2005, 24, 1982; (b) W. J. Evans, B. M. Schmiege, S. E. Lorenz, K. A. Miller, T. M. Champagne, J. W. Ziller, A. G. DiPasquale and A. L. Rheingold, J. Am. Chem. Soc., 2008, 130, 8555; (c) J. Zhang, L. Ma, Y. Han, F. Han, Z. Zhang, R. Cai, Z. Chen and X. Zhou, Dalton Trans., 2009, 3298; (d) Z. Zhang, L. Zhang, Y. Li, L. Hong, Z. Chen and X. Zhou, Inorg. Chem., 2010, 49, 5715; (e) W. Yi, J. Zhang, S. Huang, L. Weng and X. Zhou, Chem.-Eur. J., 2014, 20, 867; $(f)$ D. M. Lyubov, L. Luconi, A. Rossin, G. Tuci, A. V. Cherkasov, G. K. Fukin, G. Giambastiani and A. A. Trifonov, Chem.-Eur. J., 2014, 20, 3487.

11 I. V. Basalov, D. M. Lyubov, G. K. Fukin, A. V. Cherkasov and A. A. Trifonov, Organometallics, 2013, 32, 1507.

12 H. Li, Y. Yao, Q. Shen and L. Weng, Organometallics, 2002, 21, 2529.

13 (a) G. Hafelinger, Chem. Ber., 1970, 103, 2920; (b) F. H. Allen, O. Kennard, D. G. Watson, L. Brammer, A. G. Orpen and R. Taylor, J. Chem. Soc., Perkin Trans. 2, 1987, S1.

14 (a) B. Wang, K. Lv and D. Cui, Macromolecules, 2008, 41, 1983; (b) G. Du, Y. Wei, L. Ai, Y. Chen, Q. Xu, X. Liu, S. Zhang, Z. Hou and X. Li, Organometallics, 2011, 30, 160; (c) C. Yao, D. Liu, P. Li, C. Wu, S. Li, B. Liu and D. Cui, Organometallics, 2014, 33, 684.

15 L. Zhang, M. Nishiura, M. Yuki, Y. Luo and Z. Hou, Angew. Chem., Int. Ed., 2008, 47, 2642.

16 W. Zhang, M. Nishiura, T. Mashiko and Z. Hou, Chem.-Eur. J., 2008, 14, 2167.

17 SAINTPlus Data Reduction and Correction Program v. $6.02 a$, Bruker AXS, Madison, WI, 2000.

18 G. M. Heldrick, A. ADABS, Program for Empirical Absorption Correction, University of Göttingen, Göttingen, Germany, 1998.

19 (a) G. M. Sheldrick, SHELXL-97, Program for the Refinement of Crystal Structures, University of Göttingen, Göttingen, Germany, 1997; (b) G. M. Sheldrick, Acta Crystallogr., Sect. C: Struct. Chem., 2015, 71, 3. 